Review

\title{
A Signaling View into the Inflammatory Tumor Microenvironment
}

\author{
Joana F. S. Pereira ${ }^{1,2}$, Peter Jordan ${ }^{1,2}\left(\mathbb{D}\right.$ and Paulo Matos ${ }^{1,2, *(1)}$ \\ 1 BioISI-Biosystems \& Integrative Sciences Institute, Faculty of Sciences, University of Lisbon, \\ 1749-016 Lisbon, Portugal; joana.pereira@insa.min-saude.pt (J.F.S.P.); peter.jordan@insa.min-saude.pt (P.J.) \\ 2 Department of Human Genetics, National Health Institute 'Dr. Ricardo Jorge', 1649-016 Lisbon, Portugal \\ * Correspondence: paulo.matos@insa.min-saude.pt
}

Citation: Pereira, J.F.S.; Jordan, P.; Matos, P. A Signaling View into the Inflammatory Tumor

Microenvironment. Immuno 2021, 1 , 91-118. https://doi.org/10.3390/ immuno1020007

Academic Editor: Toshihiko Torigoe

Received: 30 April 2021

Accepted: 10 June 2021

Published: 15 June 2021

Publisher's Note: MDPI stays neutral with regard to jurisdictional claims in published maps and institutional affiliations.

Copyright: (c) 2021 by the authors. Licensee MDPI, Basel, Switzerland. This article is an open access article distributed under the terms and conditions of the Creative Commons Attribution (CC BY) license (https:// creativecommons.org/licenses/by/ $4.0 /)$.

\begin{abstract}
The development of tumors requires an initiator event, usually exposure to DNA damaging agents that cause genetic alterations such as gene mutations or chromosomal abnormalities, leading to deregulated cell proliferation. Although the mere stochastic accumulation of further mutations may cause tumor progression, it is now clear that an inflammatory microenvironment has a major tumor-promoting influence on initiated cells, in particular when a chronic inflammatory reaction already existed before the initiated tumor cell was formed. Moreover, inflammatory cells become mobilized in response to signals emanating from tumor cells. In both cases, the microenvironment provides signals that initiated tumor cells perceive by membrane receptors and transduce via downstream kinase cascades to modulate multiple cellular processes and respond with changes in cell gene expression, metabolism, and morphology. Cytokines, chemokines, and growth factors are examples of major signals secreted by immune cells, fibroblast, and endothelial cells and mediate an intricate cell-cell crosstalk in an inflammatory microenvironment, which contributes to increased cancer cell survival, phenotypic plasticity and adaptation to surrounding tissue conditions. Eventually, consequent changes in extracellular matrix stiffness and architecture, coupled with additional genetic alterations, further fortify the malignant progression of tumor cells, priming them for invasion and metastasis. Here, we provide an overview of the current knowledge on the composition of the inflammatory tumor microenvironment, with an emphasis on the major signals and signal-transducing events mediating different aspects of stromal cell-tumor cell communication that ultimately lead to malignant progression.
\end{abstract}

Keywords: tumor microenvironment; inflammation; signal transduction; cancer

\section{Introduction}

In the human body, complex physiological processes need to be coordinated at a cellular level. Circulating cytokines, hormones, and growth factors control aspects such as cell proliferation, differentiation, metabolism, angiogenesis, apoptosis, and senescence. Cells respond to such signals from their environment through sensors at the cell surface, namely receptor proteins that propagate their activation to intracellular proteins via sequential protein kinase signaling, often translocating into the nucleus, where transcription factors become activated, resulting in changes in gene expression that subsequently alter the cell's biological responses.

Tumor cells develop several well-defined features that cause dysregulation of cellular signal transduction pathways, leading to increased cell proliferation, resistance to apoptosis, metabolic changes, genetic instability, induction of angiogenesis, and increased migratory capacity. This dysregulation involves genetic mutations and epigenetic changes in the tumor cells but also a complex interplay and exchange of signals with surrounding non-neoplastic cells and the extracellular matrix (ECM), designated as the tumor microenvironment (TME) [1,2]. 


\section{The Tumor Microenvironment (TME)}

Interactions between malignant and non-transformed cells define the tumor microenvironment and are nowadays recognized as being of vital importance in the tumorigenic process. Intercellular communication is driven by a complex and dynamic network of cytokines, chemokines, growth factors, and inflammatory and matrix remodeling enzymes, all of which respond to perturbations in the physical and chemical properties of the tissue [2].

Besides these soluble factors, the tumor microenvironment (TME) consists of an extracellular matrix (ECM) as well as cellular players, such as fibroblasts and cancer-associated fibroblasts (CAFs), neuroendocrine cells, adipose cells, immune cells such as tumor associated neutrophils (TANs), myeloid-derived suppressor cells (MDSCs), monocytes and tumor-associated macrophages (TAMs), mast cells, CD8+ and CD4+ T- cells, dendritic cells (DCs), or natural killer (NK) cells, and vascular networks of blood and lymphatic vessels lined by endothelial cells (Figure 1). This TME can provide a complex functional support to potentiate cancer progression and metastasis [3-5], and also modulate responses to therapy [2].


Figure 1. Diagram depicting some of the key molecular and cellular changes that are mediated by soluble cytokines in the TME and promote cancer development (see text for details). Figure created with BioRender.com.

Indeed, over the past decade, solid tumors have increasingly been recognized as organs that consist not only of cancer cells but also a variety of morphologically distinct cells, which are described in the following and can be classified into three main groups: cells of hematopoietic origin, cells of mesenchymal origin, and non-cellular components [6]. 


\subsection{Cancer Cells}

Cancer cells are at the basis of the disease: they initiate tumor formation and drive tumor progression forward, carrying the oncogenic and tumor suppressor gene mutations that define cancer as a genetic disease. Traditionally, the cancer cells within tumors are portrayed as cell populations of clonal origin, but in the course of tumor progression, hyperproliferation combined with increased genetic instability spawn distinct clonal subpopulations [7]. Reflecting such clonal heterogeneity, many human tumors are histopathologically diverse, containing regions demarcated by various degrees of differentiation, proliferation, vascularity, inflammation, and invasiveness. Tumor heterogeneity may be responsible for tumor progression, metastasis, resistance to therapy, and relapse $[7,8]$.

In recent years, evidence has emerged of the existence of a new dimension of intratumor heterogeneity and a hitherto-unappreciated subclass of neoplastic cells within tumors, termed cancer stem cells (CSCs). CSCs share similar properties with normal stem cells, including the ability to self-renew and differentiate into heterogeneous mature cancer cells that make up the bulk of the tumor [9]. Due to this similarity, CSCs are commonly characterized by the expression of surface markers associated with stem cells, such as CD133, CD44, and CD90, which allow their identification and isolation [10]. Notably, however, there is evidence that mature cancer cells are capable of high phenotypic plasticity, allowing them to regain stem cell characters under stress conditions [9]. Moreover, recent data indicates that TME-derived signals, including inflammatory factors, can determine the generation of CSCs pools with distinct functional transition states [11]. On one hand, there are CSCs pools (termed cyclic CSCs) that exhibit a predominantly epithelial phenotype and can self-renew or differentiate into mature cancer cells. On the other hand, there are pools of autophagic (non-cyclic) CSCs that show an enhanced ability to resist apoptosis, escape immunosurveillance, survive chemotherapies, and present with a predominant mesenchymal phenotype that facilitates invasion and metastasis [11]. Differences in phenotypic plasticity may form the basis of the differential impact of therapeutic outcomes on heterogeneous subpopulations of CSCs and mature cancer cells.

CSCs reside in particular tumor microenvironment niches that play an important role in regulating their proliferation, renewal, differentiation, and stemness. CSC regulation by their niche operates through cell-cell interaction, secreted factors, cell-matrix interaction, and the biophysical properties of the niche, such as hypoxia. CSCs may also be inherently resistant to medical therapy and contribute to tumor relapse [12].

\subsection{Cells of Mesenchymal Origin}

\subsubsection{Cancer-Associated Fibroblasts (CAFs)}

Fibroblasts are non-epithelial, non-immune cells with a likely mesenchymal lineage origin, and are part of the diverse connective tissue components [13]. Fibroblasts in normal tissues are generally single cells present in the interstitial space or occasionally near a capillary, without any association with a basement membrane but embedded within the fibrillar ECM of the interstitium. Without question, fibroblasts are the most versatile and extensively studied cells in vitro owing to their ease of isolation and culture. Tissue-resident fibroblasts are usually quiescent and become activated in a wound healing response, regulating the proliferation and differentiation of epithelial tissues [14].

After activation by the presence of tumor cells, fibroblasts are known as CAFs. Besides tissue fibroblasts, CAFs can also be derived from multiple resident cell types, including epithelial cells, endothelial cells, adipocytes or mesenchymal or hematopoietic stem cells $[2,15]$. It has been postulated that about $40 \%$ of CAFs are formed from endothelial cells [15].

Recent biomarker studies have defined in more detail distinct coexisting subtypes of CAFs in the TME. CAFs expressing high levels of $\alpha \mathrm{SMA}$, named myofibroblastic CAFs (myCAF), are tumor-suppressing, whereas cells expressing low levels of $\alpha$ SMA but high levels of cytokines and chemokines are named inflammatory CAFs (iCAFs) and have tumor-promoting effects [16]. CAFs have a significant impact on cancer progression: 
they remodel the ECM, stimulate cancer cell proliferation via the secretion of growth factors, recruit inflammatory cells, induce angiogenesis, and produce immune suppressive cytokines. Through their activity, CAFs influence mesenchymal-epithelial cell interactions, the formation of CSC niches, drug access, and therapy responses $[5,14,15,17]$.

Targeting CAFs by altering their numbers, subtype, or functionality is being explored as an avenue to improve cancer therapies. However, research in this area faces numerous challenges because it still remains unclear which stimuli regulate the balance between CAFs with either pro-tumorigenic or anti-tumorigenic effects [17]. Various studies suggest that under certain stimuli, CAFs can acquire a pro-inflammatory signature characterized by the expression of immunomodulatory molecules (e.g., TGF- $\beta$ or PD-L1/L2), as well as chemokines that promote recruitment of immunosuppressive myeloid cells $[18,19]$. Moreover, CAFs can also act on tumor cells to render them more resistant to the cytotoxic activity of natural killer (NK) cells. In contrast, CAF-secreted matrix metalloproteinases (MMPs) decrease the expression of MHC class I chain-related protein A and B (MICA/B) in melanoma cells, which are required for NK cells to recognize malignant cells [20]. Thus, CAFs appear to play several important roles in the anti-tumor immune response.

Many patient studies have documented how either CAF number or CAF function is linked to outcome [21,22], and thus any ability to target CAFs would represent an appealing addition to the suite of anticancer therapies. Further targeting mechanisms, such as TGF- $\beta$ signaling that activate CAFs or emanate from CAFs to modulate the tumor phenotype, are being intensively explored to treat colorectal cancer [23]. More recently, there is a growing appreciation of the ability of CAFs to modulate the immune response [24].

\subsubsection{Endothelial Cells (ECs)}

The vascular endothelium is a versatile structure that separates the circulating blood from tissues. Moreover, apart from regulation and maintenance of blood fluidity, it plays multifunctional roles in the delivery of water and nutrients, maintenance of metabolic homeostasis, trafficking of immune cells, activation of innate and acquired immune responses, as well as angiogenesis [25].

In the initial tumor stage, tumor cells absorb oxygen and nutrients to survive and proliferate by diffusion. Their microenvironment then undergoes hypoxia and acidification as a result of excess metabolic products. When tumor volume exceeds $1-2 \mathrm{~mm}^{3}$, the tumor must become angiogenic and recruit new vasculature to grow. Cancer cells, together with tumor-associated stromal cells, stimulate the development of new blood vessels, using various mechanisms of tumor angiogenesis, including sprouting of nearby vessels [26]. When a quiescent blood vessel senses an angiogenic signal from malignant or inflammatory cells, or owing to hypoxic conditions in the TME, new vessels sprout from the existing vasculature [27]. Many soluble factors present in the TME, such as vascular endothelial growth factors (VEGFs), fibroblast growth factors (FGFs), platelet-derived growth factors (PDGFs), and chemokines stimulate endothelial cells and their associated pericytes during the neovascularization that is needed for cancer growth. Hypoxia-induced factor- $1 \alpha$ (HIF$1 \alpha$ ) is the main factor that initiates sprouting [28]. Blood vessels can also be formed by ECs recruited from the surrounding tissue as tumor endothelial cells (TECs) [28]. The tumor vasculature, in contrast to well-differentiated normal vessels, is abnormal in almost every aspect of its structure and function [29]. These aspects are targeted by many new cancer therapies because solid tumors are dependent on blood vessels for growth [28].

\subsection{Immune Cells}

\subsubsection{Tumor-Associated Macrophages (TAMs)}

Macrophages are myeloid-derived tissue sentinels that maintain tissue integrity by eliminating damaged cells and matrices for tissue repair [30].

Despite the initial hypothesis that macrophages are involved in antitumor immunity, there is now abundant evidence from human and experimental mouse cancer models that 
their activities in the majority of cases are pro-tumorigenic and enhance tumor progression to malignancy $[2,31]$.

The tumor-promoting functions of macrophages at the primary site include supporting tumor-associated angiogenesis, promotion of tumor cell invasion, migration and intravasation, as well as suppression of antitumor immune responses [1]. Moreover, macrophage-derived osteoclasts can facilitate metastatic cell colonization by remodeling bone to create an environment that is receptive to transiting cancer cells, allowing them to survive and proliferate [32].

There is pre-clinical and clinical evidence that an abundance of TAMs in the TME is associated with poor prognosis, e.g., for breast cancer $[33,34]$ or lung cancer $[35,36]$. Additionally, gene array studies in follicular lymphoma have demonstrated that the expression of genes that are associated with a strong 'macrophage' signature confers a poor prognosis, independent of other clinical variables [2,37]. However, there are examples of TAMs correlated with good prognosis of cancer [34,38].

In the literature, there are several terms and definitions to describe macrophage activation and polarization. One of the most used nomenclatures, introduced in 2000, classifies macrophages into two major subtypes: M1 and M2 [39]. M1 or classical macrophages, activated with LPS and/or interferon gamma (INF- $\gamma$ ), have a pro-inflammatory phenotype with pathogen-killing abilities, whereas M2 or alternative macrophages, activated with interleukin (IL)-4, promote cell proliferation and tissue repair and are immunosuppressive, which also promotes tumor growth [40]. M1 macrophages produce cytokines such as IL-6 and tumor necrosis factor $\alpha(\mathrm{TNF}-\alpha)$, while M2 macrophages produce TGF- $\beta$ and IL-10 to start tissue repair. Although in this linear view, M1 and M2 macrophages represent two extreme ends [41], the M2 designation has rapidly expanded to include essentially all other types of macrophages, with dramatic differences in their biochemistry and physiology, arising as a class of regulatory macrophages. Nevertheless, currently the definition of macrophage populations continues to be defined by the different expression of marker proteins [42,43].

The role of macrophages in cancer is controversial and many aspects indicate opposing roles [44]. While classically activated macrophages would act as anti-tumorigenic in later tumor stages, they have the potential to promote the earliest stages of neoplasia [45], primarily because the free radicals that they produce can lead to DNA damage and cause mutations in surrounding cells that can promote transformation. However, as tumors progress and grow, the TME markedly influences tumor-associated macrophages. These macrophages change their physiology and take on a phenotype that is more closely to regulatory macrophages.

Many observations indicate that TAMs exhibit several M2-associated pro-tumoral functions, including promotion of angiogenesis, matrix remodeling, and suppression of adaptive immunity [46].

\subsubsection{Tumor-Associated Neutrophils (TANs)}

Neutrophils represent $50-70 \%$ of the myeloid-derived white circulating cells in human blood. Normally, neutrophils contain a nucleus divided into 2-5 lobes connected by chromatin and, when circulating in the bloodstream and inactivated, neutrophils are spherical. Once activated, they change shape and become more amorphous or amoeba-like and can extend pseudopods as they hunt for antigen-containing cells or structures [47]. Several studies have reported high neutrophil counts in the peripheral blood of cancer patients, particularly in those with advanced-stage disease, and a high circulating neutrophil-tolymphocyte ratio is considered a strong indicator of poor prognosis in various cancer types [48].

The role played by tumor infiltrating neutrophils, known as tumor-associated neutrophils (TANs), in TME architecture and in tumor development is still limited [48]. Neutrophils are chemotactic phagocytes that migrate toward the site of inflammation, and their engagement by cytokines and chemokines from the TME is thought to recruit these cells to 
the tumor niche [49]. Similar to TAMs, TANs can be classified in N1 neutrophils, with an anti-tumor activity, and N2 neutrophils, with pro-tumor activity [47].

$\mathrm{N} 1$ neutrophil polarization is induced by type 1 interferon (IFN), and N1 cells express high levels of CD54/ICAM- 1 and CD95/FASR at the cell surface, whereas TGF- $\beta$ is a major determinant for $\mathrm{N} 2$ polarization, and these can be distinguished by their high expression of CD182 [50]. Notably, most neutrophils in the TME of solid tumors have an N2 phenotype [47]. After being recruited to the TME, polarized TANs participate in the remodeling process of the TME by promoting tumor angiogenesis and suppressing anti-tumor immunity. These cells act by secreting both pro-inflammatory and immunosuppressive factors, as well as pro-angiogenic factors, including IL-17, VEGF, MMP-9, IL-8, and angiopoietin-1 (ANG1) [50,51]. TANs have also been shown to participate in immune response modulation by antigen presentation, inhibition of $\mathrm{T}$ cell responses, and induction of B cell conversion [47,52-54].

It has been suggested that the plasticity and anti-inflammatory properties of $\mathrm{N} 1$ TANs could be exploited to control excessive inflammation in the TME [50]. However, the tumor-promoting effects of TANs seem to be more prominent than their anti-tumor effects [48]. Under the influence of the tumor microenvironment, TANs maintain the N2 phenotype in many solid tumors [47]. Moreover, it has been suggested that the interplay between TANs and tumor cells has an important role in the establishment of metastatic niches [55]. For example, the enhancement of lung metastasis of breast cancer cells after 5-fluorouracil (5-FU) administration is related with increased expression of neutrophilic chemokines CXCL1 and 2 by metastatic cells, which induce the intrapulmonary infiltration of large numbers of TANs expressing high levels prokineticin 2 that, in turn, promote the proliferation of the metastatic cells [56].

Neutrophils are also activated to form neutrophil extracellular traps (NETs) in the TME. NETs are networks of extracellular fibers, primarily composed of neutrophil-derived DNA, that are part of the innate immune response, designed to bind and trap pathogens [57]. It has been reported that IL-8 expression by tumor cells not only recruits neutrophils to tumor lesions, but also stimulates their IL-8 receptors, CXCR1 and CXCR2, triggering NET release into the TME [57], which wrap and coat tumor cells shielding them from CTL and NK cell-mediated cytotoxicity [58]. In addition, it has been reported that NETs are rich in serine proteases that degrade cytokines and chemokines inhibiting inflammation [59], which may also contribute to an immune-suppressive TME.

\subsubsection{T Lymphocytes}

There are many different $\mathrm{T}$ cell populations within the TME that infiltrate the tumor at the invasive margin and in draining lymphoid organs. Cytotoxic CD8+ memory $\mathrm{T}$ cells, which are normally antigen 'experienced' and capable of killing tumor cells, and CD4+ T helper 1 cells, which are characterized by the production of the cytokines IL-2 and IFN- $\gamma$, are strongly associated with a good prognosis in a lot of cancer types, such as melanoma [60,61], breast cancer [62,63], colorectal cancer [64-66], lung carcinoma [67,68], and renal cancer [69]. In these last two types, there is also contradictory evidence associating the presence of the CD8+ lymphocytes with a poor prognosis [69,70].

Another type of Thelper cells, such as TH2, TH17, or immunosuppressive T regulatory (Treg), are generally thought to promote tumor growth and correlate with worse prognosis in many types of cancer [67-69]. However, Tregs can also be tumor-suppressive and their presence in Hodgkin's Lymphoma correlates with a good prognosis, presumably through a direct suppression of tumor cell growth [71,72].

Regulatory pathways that limit the immune response to cancer are becoming increasingly well-characterized and targets for immunotherapy. One good example is Cytotoxic T-lymphocyte-associated antigen 4 (CTLA-4), which is an immune checkpoint molecule that downregulates pathways of T-cell activation [73]. CTLA-4-directed immunotherapy is used in a range of solid tumors, such as melanoma [74]. 
Another example is programmed cell death 1 (PD-1) and programmed cell death ligand 1 (PD-L1), since this signaling pathway plays a key role in physiological immune homeostasis. PD-1 signaling negatively regulates $\mathrm{T}$ cell-mediated immune responses and serves as a mechanism for tumors to evade the immune system. The development and application of immune checkpoint inhibitors that block PD-1/PD-L1 interaction result in very durable responses and prolong survival in patients with a wide range of cancers. There is an increasing number of different FDA-approved drugs for this immunotherapy [75] that targets the TME instead of the tumor cell.

Recent evidence has highlighted NKG2D, an activating cell surface receptor that is predominantly expressed on cytotoxic immune cells, as a potential therapeutic target in cancer, since it has the potency to enhance cytolytic immune responses against tumor cells [76]. CD4+ T cells generally do not express NKG2D even after activation, but its expression can be induced under certain inflammatory conditions, such as Crohn's disease [77]. NKG2D binds to number of structurally different MHC-I-like ligands whose expression is upregulated in conditions of cellular stress, including oncogenic transformation [78]. Engagement of NKG2D stimulates the production of cytokines and cytotoxic molecules and it has been shown to participate in immune responses against a variety of tumors, playing an important role in the recognition and elimination of altered cells [79]. However, given the complexity of NKG2D-mediated responses, further research will be required before the biology of this receptor can be harnessed therapeutically $[76,79]$.

\subsubsection{B Lymphocytes}

B lymphocytes carry antibodies inserted into the plasma membrane as part of Bcell receptors and differentiate into antibody-secreting effector cells upon recognition of the cognate antigen. Besides this humoral immunity response, tumor-infiltrating B cells (TIBs) can be found at the invasive margin of tumors, but are more common in lymphoid structures adjacent to the TME and associated with good prognosis in some breast and ovarian cancers [80,81]; however, in mouse models, in which B cells inhibit tumor-specific cytotoxic $\mathrm{T}$ cell responses [82], the role of B cells is tumor-promoting [83,84].

In the TME, TIBs shape the immune response by affecting other immune cells in the surrounding lymphoid tissue [85,86] and modulating the activity of myeloid cells [83].

\subsubsection{Other Immune Cells}

Innate lymphoid cells (ILCs) are a recently characterized family of innate immune cells, derived from common lymphoid progenitors, that are important for tissue homeostasis and for the initiation of immune responses [87]. ILCs represent a heterogeneous population of innate immune cells. In contrast to adaptive immune cells (T and B lymphocytes), ILCs lack the somatic rearrangement of antigen-specific receptors and do not express either Tor B-cell receptors (TCR or BCR) $[87,88]$.

Based on their transcriptional regulation and cytokine profiles, ILCs can be categorized into different subsets with defined phenotypes and functional profiles: NK cells, ILC1, intraepithelial ILC1 (ieILC1), ILC2, ILC3, lymphoid tissues inducer (LTi), and ILC progenitor (ILCP) cells [88]. It should be noted, however, that ILCs have the ability to adapt to local environmental cues by changing these profiles [89].

The activation and selective accumulation of ILC subsets have been observed in several types of inflammatory diseases [89]. For example, IFN- $\gamma$-producing ILC1s and IL-17-producing ILC3s accumulate in the inflamed tissues of patients with Crohn's disease, accompanied by a decrease in the number of IL-22-producing ILC3s, and these changes in ILC composition correlate with disease severity [90].

Tumors are infiltrated with a large number of lymphocytes and the ability of ILCs to respond rapidly to signals in the TME has led to the suggestion that they might have a role in the immune response to tumors [91]. Nevertheless, the development and behavior of NK cells and other ILCs in the context of cancer is still incompletely understood. For instance, NK cells and NKT cells (which share the characteristics of both T and natural 
killer cells), are known to infiltrate the tumor stroma, but are usually not found in contact with tumor cells. For many cancers, such as colorectal, gastric, lung, renal, and liver, their presence appears to predict a good prognosis [92-96].

Dendritic cells (DCs) have important functions in antigen processing and presentation. The DCs that are found in the TME are thought to be suppressed, that is, they cannot adequately stimulate an immune response to tumor-associated antigens, maybe due to the hypoxic and inflammatory conditions in the TME that inhibit their activation [97].

Myeloid-derived suppressor cells (MDSCs) are immature myeloid cells. In contrast to TAMs and TANs, the number of MDSCs in the TME is negatively correlated with the number of tumor infiltrating T cells [98]. However, MDSCs are closely influenced by tumor hypoxic conditions, and they can rapidly differentiate into TAMs in the TME [99]. It is worth noting that MDSCs can have powerful immunosuppressive properties. MDSCs migrate into inflammatory and hypoxic tumor tissues and produce a large number of HIF- $1 \alpha$-mediated immunosuppressive cytokines (such as Arg1, NO, TGF- $\beta$, IL-10) and chemokines (such as CCL4 and CCL5) attracting Tregs to the tumor [99]. Consistent with the function of Treg cells, MDSCs inhibit T cell tolerance by increasing the expression of PD-L1 and CTLA-4 receptors [98].

The immune cell populations infiltrating human tumors are highly complex and due to their synergistic or opposing effects, it is difficult to predict their activity. They may influence tumors differently depending on their histological and molecular type, their stage, the microenvironment of the organ in which they grow, or the nature of the primary tumor or its metastases [73].

Although this review attempts to provide a general overview, it is important to note that tissue-specific properties determine the TME composition and regulation. For more detailed descriptions, the reader is referred to reviews on specific tumor types, such as breast [100,101], lung [102,103], colorectal [104,105], prostate [106,107], or brain cancer $[108,109]$.

\subsection{Non-Cellular Components}

The Extracellular Matrix (ECM)

The ECM provides structure and support for the cellular components in the extracellular space of tissues and organs, but also contains cell-secreted growth factors that can be released during remodeling and contribute to paracrine cellular signaling. The ECM is comprised of highly organized interactions of fibrous molecules, proteoglycans, glycoproteins, glycosaminoglycans, and other macromolecules. It is composed of around 300 proteins in mammals and constantly remodeled by cells to control tissue homeostasis $[110,111]$.

Although long viewed as a mechanical support structure that maintains tissue morphology, the ECM is a dynamic and versatile part of the milieu of a cell, and influences fundamental key aspects of cell biology [112]. ECM composition ranges from soft and compliant to stiff and rigid and determines the mechanoperception of a cell [113-115], functioning as a major environmental cue that determines cell comportment and contributes to development and disease [116].

Components of the ECM constantly interact with epithelial cells by serving as ligands for cell receptors such as integrins or growth factors, thereby transmitting signals that regulate adhesion or migration, proliferation, apoptosis, or differentiation, and angiogenesis. Disruption or disorganization of the ECM, leads to abnormal behavior of cells and ultimately failure of organ homeostasis and function [116]. Indeed, abnormal ECM dynamics is one of the most ostensible clinical outcomes in diseases such as fibrosis [117] and are considered a hallmark of cancer [116].

Tumor-derived ECM is biochemically distinct in its composition compared with normal ECM. In consequence, the tumor stroma is typically stiffer than normal stroma, for example in breast cancer $[118,119]$ and this promotes cell transformation and metastasis. Consistent with these changes, expression of many ECM remodeling enzymes is often 
deregulated in human cancers, for example: heparanases, sulfatases, cysteine cathepsins, urokinase, and many MMPs are frequently overexpressed in different cancers [120,121].

In addition, growing evidence suggests that the ECM is an essential non-cellular component of the cell niche, both for tumors and adult stem cells. For example, ECM receptors allow stem cells to anchor to the special local niche environment where stem cell properties can be maintained. Such an anchorage physically constrains stem cells to make direct contact with niche cells, which produce paracrine signaling molecules that are essential for maintaining stem cell properties [122]. Moreover, anchorage allows stem cells to maintain cell polarity, orient their mitotic spindles, and undergo their characteristic asymmetric cell division [116].

\section{Cancer-Associated Inflammation (CAI) and the TME}

Under normal conditions, acute inflammation is a desirable, strictly regulated response to infection or tissue damage. After resolving the underlying cause, inflammation is usually associated with tissue healing processes and this is self-limiting because the production of pro-inflammatory cytokines is followed by the production of anti-inflammatory cytokines. The dysregulation of this controlled sequence of events can lead to pathogenesis, as is the case with neoplastic transformation $[4,5]$.

A tissue environment with persistent or chronic inflammation is considered today to be a risk factor for cancer development because cells infiltrating the tumor microenvironment provide tumor-supporting molecules such as cytokines and growth factors, cell survival signals, angiogenic factors, and other carcinogenesis mediators [123,124], and this promotes tumor progression and supports metastatic spread, as documented in numerous studies [46,125-128]. For example, patients with inflammatory bowel diseases (such as ulcerative colitis and Crohn's diseases, caused by both genetic and environmental factors) are at increased risk of developing colorectal cancer [129-131].

A number of other examples are purely environmental-related inflammation caused by asbestos, smoking, or silica particles associated with lung cancer [132], chronic gastritis caused by bacteria such as Helicobacter pylori associated with gastric cancer [133], E. coli infection of the prostate correlated with prostate cancer [134], a viral infection with either hepatitis virus B/C associated with hepatocellular carcinoma [135], or human papilloma virus (HPV) linked with many different cancers such as cervical and anogenital cancers, head and neck squamous cell carcinoma, esophageal carcinoma, and even ophthalmologic and breast cancers [91,136], reflux disease and Barrett's esophagus associated with esophageal cancer [137], parasitic liver flukes and primary sclerosing cholangitis correlated with cholangiocarcinoma [138], UV irradiation-associated skin inflammation related with melanoma [139], endometriosis linked with endometrial carcinoma [140], and gallbladder stone-associated chronic cholecystitis associated with gallbladder carcinoma [141].

\subsection{Mediators of Cancer-Associated Inflammation (CAI)}

Soluble components in the TME are derived both from stroma and tumor cells. The main inflammatory mediators are cytokines, which include chemokines, interferons, interleukins, and tumor necrosis factors. Some are signaling molecules that trigger a specific biological function in the receptor-expressing target cells, whereas chemokines function by attracting immune cells to sites of inflammation. Cytokines modify the behavior of both tumor and inflammatory cells, influencing the type, abundance, and activity of the latter in the TME.

\subsubsection{Pro-Inflammatory Factors}

The main primary inflammatory cytokines are IL-1 $\beta$, IL- 6 , and TNF- $\alpha$ that use type I transmembrane receptors with extracellular immunoglobulin domains for signaling [142]. These pro-inflammatory cytokines are not expressed in healthy tissue but become upregulated by an inflammatory insult to protect the host. Paradoxically, during carcinogenesis, they do not protect the host but promote cancer cell survival. In many cases, the reason 
for this paradox of cytokine function is the presence of a smoldering subclinical-level of chronic inflammation, continuously drawing in inflammatory cells $[143,144]$.

IL- $1 \beta$ is crucial to initiate acute inflammation and is mainly synthesized as a precursor protein in tissue-resident macrophages, monocytes, or neutrophils. Upon their activation, IL-1 $\beta$ is cleaved by intracellular caspase- 1 within the inflammasome complex and can then be secreted. Inflammasome activation can be initiated by cytosolic pattern recognition receptors (PRRs) in response to microbial pathogen-associated molecular patterns (PAMPs) or danger-associated molecular patterns (DAMPs) generated by the host cell. Apparently, intestinal epithelial cells also contain inflammasome components and are able to release IL-1 $\beta$ as a first line of defense against environmental pathogens that then promotes differentiation of monocytes to macrophages [145-148]. When IL-1 $\beta$ binds to a cell with IL1R, signal transduction leads to activation of the transcription factor NF- $\mathrm{kB}$, which stimulates expression of pro-inflammatory cytokine genes, including IL- 6 and TNF- $\alpha$ (see 3.2 for details). Tumor cells can also express IL1R, which in breast cancer cells was shown to stimulate IL-6 production [149], or in colon cells to drive sustained NF- $\mathrm{KB}$ activation involved in cell proliferation [150]. IL-1 $\beta$ further promotes tumor development by stimulating secretion of VEGF by malignant cells and influencing angiogenesis to increase blood vessel density in tumors $[148,151,152]$.

Altogether, IL-1 $\beta$ in the TME is generally pro-tumorigenic, sustaining chronic nonresolved inflammation, endothelial cell activation, tumor angiogenesis, and the induction of immune-suppressive cells, although divergent data ascribing tumor-inhibiting effects to IL-1 $\beta$ exist [153]. Clinically, high serum levels of IL-1 $\beta$ correlate with bad prognosis in cancer patients and detection of IL- $1 \beta$ within the TME generally predicts tumor growth and metastasis [154].

IL-6 is critical in the final maturation of B-cells, T cell differentiation into Th1, Th2 and Treg phenotypes, and also inhibits functional maturation of DC to activate effector T-lymphocytes, blocking the anticancer immunity [155]. IL-6 is produced mainly by fibroblasts, monocytes, and macrophages, but also tumor cells, which can enhance IL-6 production by activated stromal fibroblasts.

IL-6R with its associated gp130 co-receptor activates JAK-STAT signaling leading to phosphorylation and nuclear translocation of STAT3 transcription factor and expression of IL-6-responsive genes (see Section 3.2 for details). IL-6-activated STAT3 has been shown to be a survival and/or proliferation factor in certain cancers [156] and high serum IL-6 levels were reported in various cancer types and associated with poor prognosis [157], with anti-IL-6 receptor antibodies showing anti-tumor and anti-angiogenic activity in vivo [158].

TNF- $\alpha$ is a potent inflammatory mediator in any inflammatory reaction of the innate immune system. It induces the expression of chemokines and endothelial and cellular adhesion molecules in order to facilitate the recruitment of effector immune cells to the site of infection [142]. TNF- $\alpha$ is first synthesized as a transmembrane precursor (mTNF- $\alpha$ ) requiring release by proteolytic cleavage through TACE (or ADAM17) [142,159]. A soluble trimer $(\mathrm{sTNF}-\alpha)$ is the ligand for TNF receptors with TNFR1 being widely expressed on different cell types. TNFR1 is a single transmembrane glycoprotein containing an intracellular death domain, to which upon activation the adaptor molecule TRADD and TRAF2 are recruited, leading to the addition of linear ubiquitin chains to RIPK1 via the ubiquitin-E3 ligase activity of TRAF2. If the formation of this so-called Complex I is successful, the ubiquitin chains act as scaffolds for additional factors that lead to the activation of NF- $\mathrm{kB}, \mathrm{JNK}$, and p38 pathways and induction of cytokine signaling and cell survival [159]. Alternatively, failure of RKIP1 ubiquitination leads to Complex II formation by recruitment of Fas-associated death domain (FADD) and activation of procaspase-8 to mediate cell death via apoptosis or necroptosis, hence the initial designation as tumor-necrosis factor [160].

The therapeutic administration of neutralizing anti-TNF- $\alpha$ antibodies effectively reduces local and systemic inflammation in patients with rheumatoid arthritis or Crohn's Disease [161] but may also increase the risk for malignant diseases [162]. 


\subsubsection{Pro-Inflammatory Chemokines in the TME}

More than 50 different chemokines exist, mainly from the CC and CXC subfamilies, that attract immune cells to sites of inflammation, including the TME [163]. One example is IL-8/CXCL8 that is recognized by the G protein-coupled receptors CXCR1 and CXCR2, and signals via phosphatidylinositol-3 kinase (PI3K) and MAPK [164] (see Section 3.2 for details). The main role of IL- 8 in inflammation is the recruitment of neutrophils but increased expression of IL-8 and/or its receptors has been characterized in cancer cells, where IL-8 acts as an autocrine growth factor inducing proliferation and preventing apoptosis. Chemokines also modulate stromal cells in the TME to release growth and angiogenic factors [164,165].

Other soluble factors in the TME are reactive oxygen species (ROS) that are secreted either by activated immune cells such as neutrophils or MDSCs, or as intercellular signaling molecule such as nitric oxide secreted by M1-type macrophages or cancer cells. Their presence can increase DNA damage and the mutation rate in cancer cells. On the other hand, excess ROS production by altered metabolism of cancer cells contributes to immunosuppression, as immune effector cells such as NK and Treg cells are inhibited by ROS [166].

\subsubsection{Anti-Inflammatory Mediators-IL-10}

Anti-inflammatory cytokines are functionally defined as those inhibiting the synthesis of pro-inflammatory cytokines such as IL-1 or TNF- $\alpha$. Their function is mainly to limit the magnitude of the immune response and prevent damage to the inflamed host tissue by allowing tissue repair and regeneration. Major anti-inflammatory cytokines include IL-1 receptor antagonist (ra), IL-4, IL-10, IL-11, and IL-13, but also soluble and decoy variants of TNF, IL-1, or IL-18 receptors.

A key immunosuppressive cytokine is IL-10, which is produced by a variety of immune but also non-hematopoietic and cancer cells. Upon binding of IL-10, the receptor IL-10R inhibits the activation of NF-KB and STAT3 that are required for transcription of pro-inflammatory cytokine genes [167].

IL-10 is an essential regulator of intestinal homeostasis, and mice and humans deficient in either IL-10 or its receptor (IL-10R) develop spontaneous intestinal inflammation. In addition, polymorphisms or mutations in the IL-10 locus confer increased genetic risk for developing ulcerative colitis or Crohn's disease [168-170]. Another phenomenon of insufficient anti-inflammatory response is known as the cytokine storm, characterized by an aggressive pro-inflammatory response with loss of homeostasis of the immune response to either pathogens, like SARS-CoV-2 [171] or in response to cancer immunotherapy [172,173].

The presence of IL-10 in the TME may thus suggest that it undermines the immune response of macrophages to cancer; however, IL-10 is also required for the expansion of tumor-specific cytotoxic CD8+ T cells to control tumor cells [174].

\subsubsection{The Transforming Growth Factor- $\beta$ (TGF- $\beta$ )}

Virtually all human cell types are responsive to TGF- $\beta$ and a dual role has been described in relation to cancer.

In normal or initiated cancer cells, TGF- $\beta$ suppresses growth. The active TGF- $\beta$ dimer activates a pair of receptor serine/threonine kinases known as the type I and type II receptors, which propagate the signal by phosphorylating Smad transcription factors. After trimerization, phospho-SMAD2, SMAD3, and SMAD4 translocate to the nucleus and bind to their specific SMAD binding element in the promoter of target genes. For its growthinhibitory effect, Smads mobilize cyclin-dependent kinase (CDK) inhibitors and suppress expression of c-Myc. Later in tumorigenesis, mutations in the tumor-suppressive arm of the pathway (e.g., the TGFBR2 or SMAD4 genes) allows TGF- $\beta$ to promote expression of the transcription factors SNAIL and SLUG, which stimulate EMT and invasiveness [175].

In the TME, TGF- $\beta$ is mostly secreted by TAMs and Tregs as an immune-suppressive molecule [176]. Similar to IL-10, TGF- $\beta$ inactivates NK cells and promotes differentiation of 
TAN into the $\mathrm{N} 2$ phenotype or of T cells into the Treg class [177]. TGF $\beta$ further stimulates the activation of mesenchymal stem cells, tissue fibroblasts, or endothelial cells into CAFs that produce matrix metalloproteases and degrade the ECM, facilitating tumor cell invasion, and also produce cytokines, promoting cancer cell proliferation and angiogenesis. Thus, TGF $\beta$ acts in the TME as an immune suppressor, an inducer of tumor-cell mitogens and a promoter of carcinoma invasion $[175,178]$.

\subsection{Signaling in the Inflammatory TME}

Many signaling events and pathways have been shown to mediate the contribution of inflammatory cues in the TME to the tumorigenic process. However, a set of molecules and pathways are considered to be prime drivers of cancer-associated inflammation (CAI) (summarized in Figure 2).

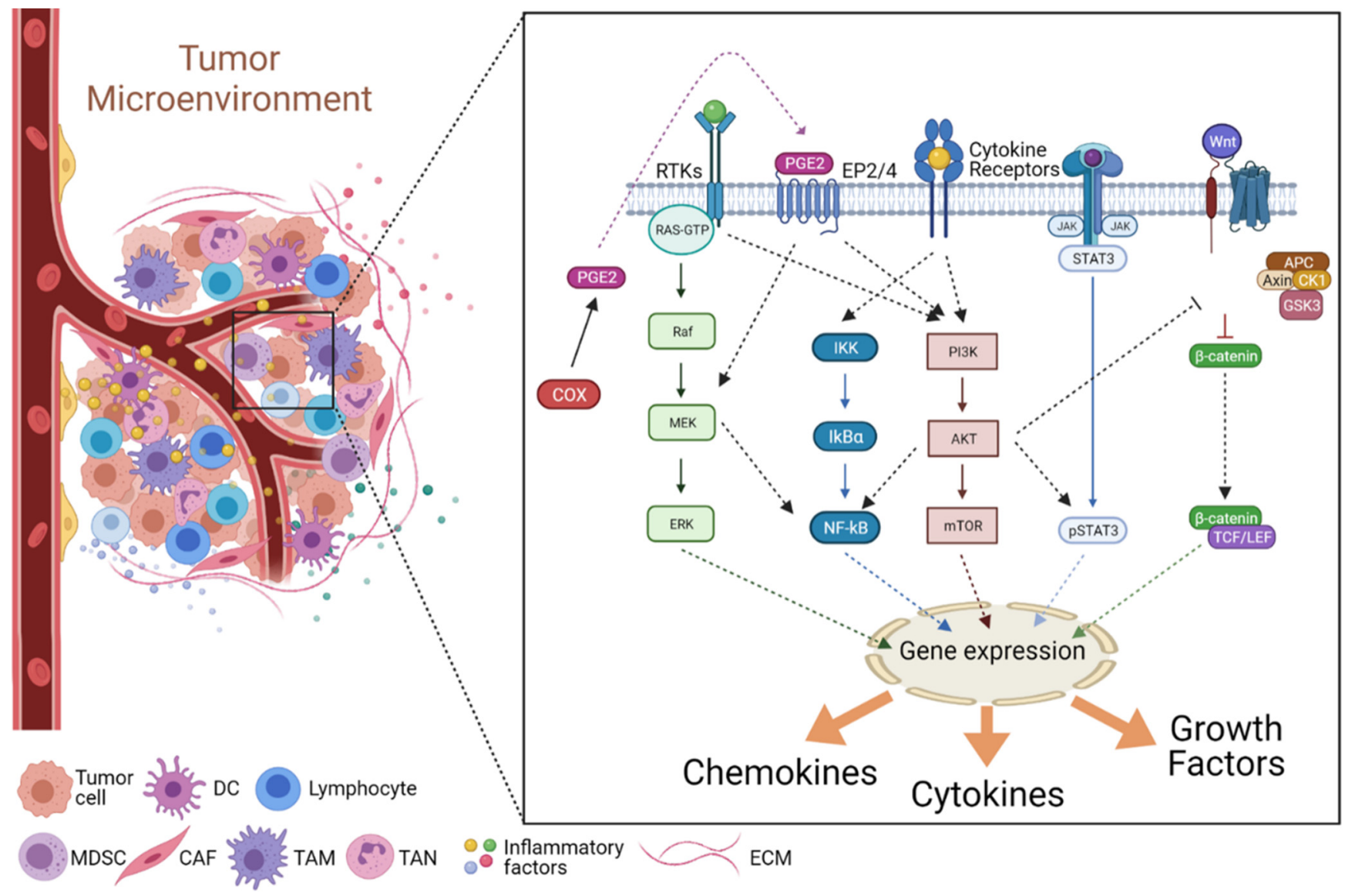

Figure 2. Schematic representation of the signaling pathways that are activated in tumor cells or tumor-associated stromal cells and modulate the interplay within the inflammatory tumor microenvironment, promoting tumor development and progression (see text for details). TAM—tumor-associated macrophage; TAN—tumor-associated neutrophil; DC—dendritic cells; CAF—cancer-associated fibroblast; MDSC—Myeloid-derived suppressor cells; ECM-Extracellular matrix. Figure created with BioRender.com.

\subsubsection{The JAK/STAT Pathway}

The Janus kinase (JAK) family of nonreceptor tyrosine kinases includes JAK1, JAK2, JAK3, and TYK2. JAK family proteins associate with the intracellular domain of cytokine receptors, transducing cytokine-induced signals to the signal transducer and activator of transcription (STAT) family of transcription factors [179]. The JAK/STAT pathway contributes to the regulation of many cellular processes, including immunity, cell growth, cell death, and differentiation. Dysregulation of JAK/STAT signaling underlies several pathogenic conditions related to chronic inflammation, autoimmune diseases, and can- 
cer [179]. Among the seven mammalian STAT family members, STAT3 has been reported as having a vital role in modulating both endogenous and exogenous inflammatory signaling in tumors, by mediating the expression of inflammatory molecules triggered by oncogenic stimuli [180].

Most of these inflammatory mediators are produced by stromal immune cells such as TAMs and MDSCs, although some are produced by the tumor cells [1]. Underlying this inflammatory interplay is the continuous upregulation of STAT3 activity, which has been detected in as many as 50\% of all human tumors [180]. In tumor cells, STAT3 promotes gene expression of many pro-inflammatory products such as IL-6, IL-10, and TNF- $\alpha$. These, in turn, stimulate immune cell receptors that activate their STAT3 signaling pathways, further potentiating the expression of pro-tumorigenic cytokines, chemokines, and growth factors, thus establishing a STAT3 positive feedback loop between tumors and the inflammatory TME [1,181].

Notably, STAT3 signaling is also known to play an important role in tumor-associated angiogenesis. Upregulated STAT3 signaling in both tumor and stromal cells leads to the production of several angiogenic stimuli [182]. For example, the pro-inflammatory cytokine IL-6 activates STAT3 via the classical IL-6R/gp130-JAK-STAT3 pathway, leading to VEGFA expression by binding of activated STAT3 to the promoter of the VEGF gene [183]. Moreover, pro-inflammatory cytokines act via STAT3 not only on stromal and tumor cells but also on endothelial cells. For instance, stimulation of endothelial cells by IL-17 induced STAT3-mediated expression and secretion of additional inflammatory factors such as growth-related oncogene- $\alpha$ (GRO- $\alpha)$, GM-CSF, and IL-8 [184]. These factors also mediate the recruitment of additional inflammatory cells, including neutrophils, to the TME, namely to the perivascular stroma, thus promoting another tumorigenic feedforward cycle [182]. Of note, it was reported that TNF- $\alpha$-induced IL-10 also participates in angiogenesis by promoting endothelial progenitor cell migration, adhesion, and tubule formation, through activation of the STAT3 pathway and induction of VEGF and MMP-9 expression [185]. Additionally, VEGF secretion also promotes breast and lung cancer stem cell self-renewal via VEGF receptor-2 (VEGFR-2)/JAK2/STAT3 pathway-mediated upregulation of MYC and SOX2 expression [186]. Finally, STAT3 activity has also been implicated in the evasion from immune surveillance, by promoting the expression of PD-L1 and PD-L2 in cancer cells, suppressing immune cell activity [187].

\subsubsection{The NF-кB Pathway}

Nuclear factor kappa-light-chain-enhancer of activated B cells (NF- $\kappa B$ ) is a transcription factor assembled by the dimerization of two of five members of the Rel family of proteins that share a Rel homology domain in their N-terminus. However, whereas subunits RelA (p65), RelB, and c-Rel, have a transactivation domain in their C-termini, the p50 and p52 subunits do not. The classical NF- $\mathrm{kB}$ heterodimer is a combination of the p65 (RelA) and p50 subunits. While in an inactivated state, NF- $\mathrm{BB}$ is located in the cytosol complexed with the inhibitory protein nuclear factor of kappa light polypeptide gene enhancer in B-cells inhibitor alpha $(\mathrm{I} \kappa \mathrm{B} \alpha)$. A variety of extracellular signals, stimulating various receptor types, result in the activation of the IKB kinase (IKK). IKK, in turn, phosphorylates the I $\kappa \mathrm{B} \alpha$ protein, which results in its dissociation from NF- $\kappa \mathrm{B}$ dimers and eventual proteasomal degradation, allowing activated NF- $\mathrm{KB}$ to translocate into the nucleus and bind to the promoters of multiple target genes [188].

Although initially identified as a central mediator of immune cell stimulation, the NF- $\kappa B$ pathway is also activated in tumor cells and has been reported to promote tumor cell proliferation, survival, and invasion [1,189-191]. Nevertheless, the upregulation of NF- $\mathrm{KB}$ activity does not seem to be associated with oncogenic mutations of Rel proteins or their direct regulators [192]. On the contrary, the activation of NF- $\mathrm{kB}$ is mainly driven by inflammatory cytokines present in the TME, such as TNF- $\alpha$, IL-6, IL-1, and IL-8 [192,193]. Indeed, persistent chronic inflammation can trigger abnormal NF- $\kappa \mathrm{B}$ activity in precancerous lesions, promoting tumor development, which is then sustained by the inflammatory 
microenvironment, induced and maintained after malignant transformation [192,194]. The magnitude of NF- $\mathrm{BB}$ upregulation in tumors has been further highlighted by recent data showing that it can be detected in high levels in the plasma of breast and colon cancer patients, correlating with increased systemic inflammation markers such as, TNF- $\alpha$, IL-6, and C-reactive protein (CRP) [195].

Notably, studies have shown that there is an important interplay between STAT3 and NF-KB signaling pathways in the development of inflammation-induced tumors. The concomitant activation of these two factors in the tumor and stromal immune cells results in secretion of a large number of tumor-promoting cytokines, including TNF- $\alpha$, IL- $1 \beta$, IL-6, IL-8, and VEGF [1,192,193]. This again triggers positive feedback loops where the inflammatory cytokines mediate the initiation signals to non-tumor stromal cells, including endothelial cells. NF- $\mathrm{BB}$ binds to the promoter of VEGFR2 and stimulates its expression in endothelial cells. The activation of VEGFR2 by the VEGF in the TME further promotes the activation of downstream angiogenesis signals in endothelial cells [196]. NF- $\mathrm{KB}$ also binds the IL- 8 gene promoter, and stimulates its transcription by stromal and tumor cells, an inflammatory chemokine that also functions as a pro-angiogenic agent [192]. By binding to the C-X-C motif chemokine receptor 2 (CXCR2), IL-8 upregulates VEGF levels in endothelial cells, also via the NF-kB pathway, leading to the autocrine activation of VEGFR2 [197].

Thus, the crosstalk between tumor and tumor-associated stromal cells feeds back to the TME, further stimulating angiogenesis but also tumor cell proliferation, epithelialmesenchymal transition (EMT), invasion, metastasis, and chemoresistance [1,181]. Indeed, NF- $\mathrm{KB}$ activation is a well-known mechanism by which chemoresistance to anticancer agents arises, namely through the upregulation of a multitude of mediators, including anti-apoptotic genes [198]. Moreover, activated NF-kB also induces the expression of MMP-2 and MMP-9, again synergizing with STAT3 activity to facilitate EMT, invasion and metastasis $[199,200]$. NF- $\mathrm{kB}$ also regulates the expression of another important mediator of the inflammatory TME, often found overexpressed in malignant tumors-cyclooxygenase-2 (COX-2) [193,201].

\subsubsection{The COX2/PGE2 Pathway}

As we discussed above, inflammatory mediators can be produced by the different stromal cell types or directly by the cancer cells themselves. Besides the crucial cytokines, chemokines, growth factors, and matrix remodeling factors already mentioned, several other tumor-sustaining mediators are known to contribute to the inflammatory microenvironment. Among this, prostaglandin E2 (PGE2) clearly stands out [202]. PGE2 is a prostanoid lipid associated with the promotion of cancer cell survival, growth, migration, and invasion, also participating in tumor-associated angiogenesis, and immunosuppression [193,202]. Cyclooxygenase (COX)-1 and -2 are the rate-limiting enzymes for prostaglandin synthesis from arachidonic acid [202]. COX-1 is constitutively expressed in a wide range of normal tissues and works as a housekeeping enzyme responsible for maintaining tissue homeostasis. COX-2 is nearly absent in most normal cells, but is often overexpressed in multiple cancers, including colorectal, breast, stomach, lung, and pancreatic cancers, and is associated with poor prognosis [201,203]. Of note, COX-2derived PGE2 has been shown to mediate the crosstalk between colonic tumor cells and TAMs [204], induce the accumulation and activation of MDSCs [205,206], and promote the tumor growth of mutant BRAFV600E melanomas by suppressing immunity and enhancing tumor-promoting inflammation [204,207,208].The depletion of COX-2 or downstream PGE2 synthases modifies the TME inflammatory signaling profile from pro-tumorigenic to anticancer pathways [193,201]. Moreover, the inhibition of COX-2 synergizes with PD-1 blockade to improve tumor cell eradication and augment the numbers of functional tumorspecific CTLs in patients with advanced epithelial ovarian cancer [209]. These data indicate the critical role of COX-2 and PGE2 in modulating the TME to an immunosuppressive status. Notably, several clinical studies have shown that the long-term use of non-steroidal anti-inflammatory drugs, which act by inhibiting COX activity, may reduce the risk of 
developing several types of cancer, although the optimal preventive drug dosages and treatment durations remain to be fully clarified [210].

Several stimuli from the inflammatory TME can elevate the expression of COX-2 or upregulate COX-2/PGE2 signaling axis. For example, TME cues were shown to activate the receptor tyrosine kinase ephrin-A receptor 2 (EPHA2), which signals through the TGF- $\beta$ pathway to stimulate COX-2 expression in pancreatic cancer [211]. In addition, reduction of Receptor-interacting protein kinase 3 (RIPK3), a key element in colonic mucosal repair, elicited NF-KB-mediated upregulation of COX-2 and consequent increased PGE2 production in colorectal cancer cells and associated MDSCs [212]. Moreover, PGE2 exacerbated the immunosuppressive activity of MDSCs, accelerated tumor growth, and further suppressed RIPK3 expression, in another example of a TME -associated feedforward cycle [212]. Notably, inhibition of COX-2 or PGE2 receptors reversed the immunosuppressive activity of MDSCs and dampened tumorigenesis [212].

In another example, histone deacetylase 6 (HDAC6), one of class II histone deacetylases, was frequently found associated with poor survival outcomes when upregulated in the CAFs from breast cancer patients [213]. HDAC6 upregulation in CAFs was a crucial epigenetic mediator to promote an immunosuppressive TME by regulating STAT3 activation and promoting STAT3-dependent expression of COX-2 and PGE2 synthesis [213]. Finally, the frequent cancer-associated aberrant activity of classical mitogen-activated protein kinase (MAPK) cascades, such as the MAPK/ERK and p38 MAPK pathways, also promoting the upregulation of COX-2/PGE2, thus favoring immunosuppressive TME and promoting the progression of various cancer types [201,214-216].

\subsubsection{The PI3K/Akt Pathway}

The phosphatidylinositol 3-kinase (PI3K)/ AKT (Protein kinase B, PKB) pathway is a crucial coordinator of intracellular signaling in response to the extracellular stimuli. Consequently, its dysregulation has been reported to have a broad role in mediating the inflammatory signaling between tumors and the TME [217]. On one hand, upstream receptor tyrosine kinases, the p $110 \alpha$ catalytic subunit of PI3K, the downstream effector kinase AKT, and the negative pathway regulator PTEN (a lipid phosphatase that dephosphorylates phosphatidylinositol $(3,4,5)$-trisphosphate (PIP3) to phosphatidylinositol (4,5)-bisphosphate (PIP2)), are all often mutated in a wide range of human tumors, contributing to the malignant transformation of cells by promoting tumor growth, but also invasion and metastasis [218]. For example, activation of mechanistic target of rapamycin (mTOR) serine/threonine kinase downstream of PI3K/AKT promotes tumor cell growth, proliferation, and survival, and also facilitates tumor cell motility through cytoskeletal reorganization [219]. Moreover, activated AKT signaling also facilitates EMT through differential phosphorylation on Twist, a key transcriptional regulator controlling cell plasticity, in response to growth factors and inflammatory cytokines in the TME [220]. On the other hand, various inflammatory factors, such as IL-1, IL-6, IL-17A, and TFN- $\alpha$, stimulate AKT activation in tumor cells and, conversely, leading to the synthesis and secretion of more inflammatory mediators, including IL-8, IL-6 and CCL2 [218,221].

As described above, the transcriptional regulation of most of these cytokines is primarily controlled by NF- $\mathrm{kB}$ and STAT3 pathways. However, NF- $\mathrm{kB}$ and STAT3 activities are also tightly controlled via cross-talks with other key intracellular pathways, including the PI3K/AKT/mTOR pathway [217]. For example, AKT can activate the IKK complex, namely through a direct mTOR-IKK interaction [222], and part of TNF- $\alpha$-induced AKT pro-oncogenic signaling is relayed through the NF- $\kappa B$ pathway [223]. In addition, in hepatocellular carcinoma, TME IL-17 robustly induced IL-6 expression and STAT3 activation in an AKT-dependent manner [224]. In turn, IL-6 activated JAK2/STAT3 signaling leading to IL-8, MMP-2, and VEGF upregulation, which promoted neutrophil infiltration and increased tumor vascularity [224].

Indeed, several reports have shown that multiple pathways downstream of activated AKT participate in the recruitment, proliferation, and differentiation of various TME- 
associated leukocytes, such as TAMs, TANs, and lymphocytes, thereby further promoting inflammation $[217,225]$. Thus, the dysregulation of PI3K/AKT signaling favors the aggregation of reactive immune cells in the TME, resulting in the release and accumulation of ROS in the tumor site by means of the oxidative stress response $[1,220]$. Notably, increased ROS levels in the TME can feedback and further stimulate AKT signaling in tumor cells. For instance, in ovarian cancer cells, epidermal growth factor (EGF)-induced increase in ROS levels promoted the activation of the AKT/mTOR/ p70 S6 Kinase 1 (p70S6K1) axis, which mediate the expression of (HIF-1 and VEGF, promoting tumor angiogenesis [226].

Interestingly, TAM-secreted IL-1 and TNF- $\alpha$ also promotes the phosphorylation of proapoptotic Bcl-2 family member BAD by activating the PI3K/AKT pathway, preventing BAD from inhibiting the activity of survival protein $\mathrm{Bcl}-2$ and $\mathrm{Bcl}-\mathrm{xL}$, favoring neovascularization by promoting endothelial cell survival through a mechanism that also involves NF- $\mathrm{kB}$ activity $[227,228]$. Notably, despite limited by resistance and adverse effects, it has been suggested that the anti-angiogenic effects of PI3K inhibitors might account, at least in part, for their reported therapeutic effectiveness within the advanced stages of multiple cancers, including lymphoma, glioblastoma multiforme, melanoma, colorectal, lung, breast, and hepatocellular carcinomas [229-231].

\subsubsection{The Wnt Pathway}

The Wnt pathway is one of the central mechanisms regulating tissue morphogenesis during embryogenesis and repair [232]. It is thus not surprising that anomalous Wnt signaling has been associated with several cancers, namely colorectal, breast, lung, oral, cervical, and hematopoietic malignancies [233].

To date, 19 distinct Wnt proteins (ligands), 10 frizzled receptors (FZD), and several co-receptors have been identified in mammals [234]. In the canonical Wnt pathway, Wnt proteins bind to their complex receptor FZD/LRP5/ 6 (low-density lipoprotein receptor related protein), preventing proteasomal degradation of $\beta$-catenin. This allows $\beta$-catenin to be translocated to the nucleus, where it binds to transcription factors of the $\mathrm{T}$ cell factor (TCF)/lymphoid enhancer factor (LEF) family, activating the expression of multiple target genes [232,235]. Conversely, in the absence of Wnt ligands, the phosphorylation of $\beta$ catenin by the so-called destruction complex (composed of axin, Adenomatous Polyposis Coli (APC), and kinases CK1, and GSK3 $\beta$ ) leads to its ubiquitination by $\beta-\operatorname{TrCP}$ ubiquitin ligase, targeting it for proteasomal degradation. As a result, the pool of $\beta$-catenin in the cytosol is depleted, and its nuclear translocation is blocked, restraining the transcription of Wnt target genes [235]. The APC protein serves as the building platform for the assembly of the $\beta$-catenin destruction complex. Loss-of-function mutations in APC, which occur early on in cancers such as colon cancer, lead to loss of $\beta$-catenin regulation and aberrant activation of Wnt signaling [235]. Indeed, familial adenomatous polyposis (FAP), an inherited condition characterized by numerous adenomatous polyps in the large intestine and highly increased risk of colon cancer, results from germline mutation in the APC gene [236].

Several growth factors secreted by stromal cells of TME have also been reported to induce the activation of Wnt signaling in tumor cells. For example, augmented hepatocyte growth factor (HGF) levels in colorectal cancer (CRC) upregulate $\beta$-catenin expression via the PI3K pathway and promote $\beta$-catenin dissociation from c-Met (HGF receptor) at the plasma membrane enhancing the activity of the $\beta$-catenin-regulated TCF family of transcription factors [237].

Also in CRC, TAMs express increasing levels of Wnt ligands Wnt2 and Wnt5a during progression from normal colorectal adenoma to carcinoma, suggesting that paracrine Wnt activation by macrophages may result in cancer progression [238]. A study, using mouse models of breast cancer, showed that Wnt $7 \mathrm{~b}$, another Wnt ligand produced by TAMs, initiated the canonical Wnt pathway in TECs expressing LRP5 and Frizzled, leading to $\beta$-catenin-mediated transcription of cell cycle genes, thus linking Wnt signaling to tumor angiogenesis [239]. 
Notably, PGE2 secreted by TECs is also known to activate $\beta$-catenin signaling and help in the proliferation of CRC cells. PGE2-stimulated EP2 receptors promote the dissociation of GSK3 $\beta$ from the destruction complex while simultaneously inducing its inactivation via PI3K/AKT-mediated phosphorylation. This leads to translocation of $\beta$-catenin to the nucleus of cancer cells, promoting tumor proliferation and progression [240].

Finally, recent evidence indicates that the aberrant expression of Wnt5a in some tumors, including melanoma, non-small-cell lung cancer, and ovarian cancer, can drive a Wnt5a/NF-kB/IL-6/STAT3 positive feedback loop that contributes to an immunosuppressive tumor microenvironment [241,242]. Wnt5a expression is upregulated by several cytokines including TNF- $\alpha$, IFN- $\gamma$, IL- $1 \beta$, and IL- 6 , in both immune and non-immune cells [243-247].

This upregulation can be prevented by pre-incubation with either NF- $\mathrm{B}$ or STAT3 inhibitors, suggesting that these pathways are implicated in Wnt5a transcription [244,248,249]. Conversely, Wnt5a can also induces NF-kB and STAT3 activity, thus generating a continuous feedforward loop in the TME [250-252]. At some point, particular subpopulations of stromal immune cells arise that respond to Wnt5a signals by promoting the synthesis of IL-10, thus generating tolerogenic microenvironments [241]. For instance, a recent study determined that a Wnt5a+CD68+/CD68+ TAMs ratio was significantly associated with poor prognosis in CRC patients and that the Wnt5a+ TAMs were of an M2-like subtype [249]. Wnt5a induced TAMs to secrete IL-10 by stimulating a CaKMII-ERK1/2-STAT3-dependent pathway, and IL-10 then acted autocrinally to induce M2 polarization of these TAMs. Furthermore, Wnt5a-induced M2 TAMs promoted CRC cells proliferation, migration and invasion, and the knockdown of Wnt5a significantly impaired the pro-tumor functions of TAMs [249].

\section{TME in Cancer: Aggressor or Innocent Bystander?}

In healthy tissue, the supporting connective tissue, or stroma, functions as an important barrier against tumorigenesis [253]. One way to look at the TME is that the presence of transformed tumor cells initiates crucial changes that convert this microenvironment into one that supports cancer progression.

For example, the breast tumor cell-derived chemokine osteopontin was found to trigger the activation of stromal fibroblasts into CAFs, which then secreted CXCL12 for tumor cell EMT [254]. In addition, overexpression of the membrane protein PD-L1 in cancer cells avoids activating $\mathrm{T}$ lymphocyte responses and mediates immune escape [255].

On the other hand, inflamed tissues are more permissive to the development of initiated tumor cells [256]. This probably explains the increased cancer risk of inflammatory bowel disease patients to develop colitis-associated colon cancer [257], or of obese individuals in whom the adipose tissue emanates inflammatory signals [258].

Moreover, there is evidence that initiated tumor cells only survive and strive when the microenvironment allows them to, for example, due to the presence of an already inflamed tissue condition. In this context, Weaver and Bissell showed how breast cancer cells with known oncogenic mutations either grow or remain quiescent depending on whether neutralizing anti-integrin antibodies block cancer cell binding to a stiff ECM [259]. Since then, the evidence for the role of the microenvironment in tumor development has increased steadily, and the targeting of a compromised immune response by immunecheckpoint inhibitors is a corresponding clinical outcome.

Indeed, cancer immunotherapy has achieved many positive clinical outcomes and is revolutionizing cancer treatment [260] (see also [100,108,163,178]). As TME is more penetrable and accessible than tumor cells, a lot of effort have recently been taken to generate inhibitors that specifically target TME (extensively reviewed in [261]). Currently, most of the agents are small molecules or antibodies, such as the Bristol-Myers Squibb (BMS) compounds that antagonize the PD-1/PD-L1 interaction [262], bindarit that targets TAMs in prostate and breast cancer [263], WRG-28 that inhibits tumor invasion and migration through CAFs in breast cancer [264], or the antibodies targeting the PD-1/PD-L1 axis (e.g., 
nivolumab), EGFR (e.g., cetuximab), and VEGF-A (e.g., bevacizumab) in metastatic colorectal and non-small cell lung carcinomas $[260,265]$. However, small molecules generally show low affinity and often cause side-effects, whereas therapeutic antibodies tend to have poor tissue penetration and costly production $[99,265,266]$. These drawbacks have recently fueled intensive research into the development of bioactive peptides capable of modulating the TME by targeting dendritic cells, MDSC, TAMs, NK cells, and Tregs; and activating antitumoral immunity, overcoming the disadvantages of previous approaches (reviewed in [266]). Nevertheless, so far, only a few peptide-based therapies have been approved for clinical usage in the oncology field [267].

So what comes first, the bad seed or the bad soil? As we have extensively discussed in this review, inflammatory signals exchanged between immune and stroma cells also act on tumor cells and have a tumor-promoting effect. This signaling view underlines a new look on cancer development that is less cancer-cell centered and less driven by accumulating genetic alterations, but rather seen as a dynamic equilibrium between the different cell types present in the TME as a constant adaptation of a new tissue-like structure, the tumor. The equilibrium is influenced by the effect that external determinants have on the TME, including microbial infections (HPV, H. pylori, gut microbioma), metabolic conditions (diet, obesity, insulin resistance, oxidative stress), and toxic compounds (tobacco, pollutants). According to this view, a combined targeting of both cancer cells and their TME should synergize and increase anti-tumor immune responses in the patient.

Funding: The work in the authors' laboratory was supported by Fundação para a Ciência e a Tecnologia (FCT), Portugal, through grant UID/MULTI/04046/2019 to Research Unit BioISI and fellowship SFRH/BD/109162/2015 to JFSP.

Conflicts of Interest: The authors declare no conflict of interest.

\section{References}

1. Li, L.; Yu, R.; Cai, T.; Chen, Z.; Lan, M.; Zou, T.; Wang, B.; Wang, Q.; Zhao, Y.; Cai, Y. Effects of Immune Cells and Cytokines on Inflammation and Immunosuppression in the Tumor Microenvironment. Int. Immunopharmacol. 2020, 88, 106939. [CrossRef]

2. Balkwill, F.R.; Capasso, M.; Hagemann, T. The Tumor Microenvironment at a Glance. J. Cell Sci. 2012, 125, 5591-5596. [CrossRef]

3. Li, H.; Fan, X.; Houghton, J. Tumor Microenvironment: The Role of the Tumor Stroma in Cancer. J. Cell. Biochem. 2007, 101, 805-815. [CrossRef] [PubMed]

4. Chen, F.; Zhuang, X.; Lin, L.; Yu, P.; Wang, Y.; Shi, Y.; Hu, G.; Sun, Y. New Horizons in Tumor Microenvironment Biology: Challenges and Opportunities. BMC Med. 2015, 13, 45. [CrossRef]

5. Wang, M.; Zhao, J.; Zhang, L.; Wei, F.; Lian, Y.; Wu, Y.; Gong, Z.; Zhang, S.; Zhou, J.; Cao, K.; et al. Role of Tumor Microenvironment in Tumorigenesis. J. Cancer 2017, 8, 761-773. [CrossRef] [PubMed]

6. Pattabiraman, D.R.; Weinberg, R.A. Tackling the Cancer Stem Cells—What Challenges Do They Pose? Nat. Rev. Drug Discov. 2014, 13, 497-512. [CrossRef] [PubMed]

7. Melo, F.D.S.E.; Vermeulen, L.; Fessler, E.; Medema, J.P. Cancer Heterogeneity-A Multifaceted View. EMBO Rep. 2013, 14, 686-695. [CrossRef] [PubMed]

8. Almendro, V.; Marusyk, A.; Polyak, K. Cellular Heterogeneity and Molecular Evolution in Cancer. Annu. Rev. Pathol. 2013, 8, 277-302. [CrossRef]

9. Clevers, H. The Cancer Stem Cell: Premises, Promises and Challenges. Nat. Med. 2011, 17, 313-319. [CrossRef]

10. Beck, B.; Blanpain, C. Unravelling Cancer Stem Cell Potential. Nat. Rev. Cancer 2013, 13, 727-738. [CrossRef]

11. Garg, M. Epithelial Plasticity, Autophagy and Metastasis: Potential Modifiers of the Crosstalk to Overcome Therapeutic Resistance. Stem Cell Rev. Rep. 2020, 16, 503-510. [CrossRef]

12. Nassar, D.; Blanpain, C. Cancer Stem Cells: Basic Concepts and Therapeutic Implications. Annu. Rev. Pathol. 2016, 11, 47-76. [CrossRef] [PubMed]

13. Darby, I.A.; Laverdet, B.; Bonté, F.; Desmoulière, A. Fibroblasts and Myofibroblasts in Wound Healing. Clin. Cosmet. Investig. Dermatol. 2014, 7, 301-311. [CrossRef] [PubMed]

14. Kalluri, R. The Biology and Function of Fibroblasts in Cancer. Nat. Rev. Cancer 2016, 16, 582-598. [CrossRef] [PubMed]

15. Kalluri, R.; Zeisberg, M. Fibroblasts in Cancer. Nat. Rev. Cancer 2006, 6, 392-401. [CrossRef] [PubMed]

16. Han, C.; Liu, T.; Yin, R. Biomarkers for Cancer-Associated Fibroblasts. Biomark. Res. 2020, 8, 64. [CrossRef]

17. Sahai, E.; Astsaturov, I.; Cukierman, E.; DeNardo, D.G.; Egeblad, M.; Evans, R.M.; Fearon, D.; Greten, F.R.; Hingorani, S.R.; Hunter, T.; et al. A Framework for Advancing Our Understanding of Cancer-Associated Fibroblasts. Nat. Rev. Cancer 2020, 20, 174-186. [CrossRef] 
18. Bhowmick, N.A.; Chytil, A.; Plieth, D.; Gorska, A.E.; Dumont, N.; Shappell, S.; Washington, M.K.; Neilson, E.G.; Moses, H.L. TGF-Beta Signaling in Fibroblasts Modulates the Oncogenic Potential of Adjacent Epithelia. Science 2004, 303, 848-851. [CrossRef]

19. Giraldo, N.A.; Sanchez-Salas, R.; Peske, J.D.; Vano, Y.; Becht, E.; Petitprez, F.; Validire, P.; Ingels, A.; Cathelineau, X.; Fridman, W.H.; et al. The Clinical Role of the TME in Solid Cancer. Br. J. Cancer 2019, 120, 45-53. [CrossRef]

20. Ziani, L.; Safta-Saadoun, T.B.; Gourbeix, J.; Cavalcanti, A.; Robert, C.; Favre, G.; Chouaib, S.; Thiery, J. Melanoma-Associated Fibroblasts Decrease Tumor Cell Susceptibility to NK Cell-Mediated Killing through Matrix-Metalloproteinases Secretion. Oncotarget 2017, 8, 19780-19794. [CrossRef]

21. Calon, A.; Lonardo, E.; Berenguer-Llergo, A.; Espinet, E.; Hernando-Momblona, X.; Iglesias, M.; Sevillano, M.; Palomo-Ponce, S.; Tauriello, D.V.F.; Byrom, D.; et al. Stromal Gene Expression Defines Poor-Prognosis Subtypes in Colorectal Cancer. Nat. Genet. 2015, 47, 320-329. [CrossRef]

22. Franco-Barraza, J.; Francescone, R.; Luong, T.; Shah, N.; Madhani, R.; Cukierman, G.; Dulaimi, E.; Devarajan, K.; Egleston, B.L.; Nicolas, E.; et al. Matrix-Regulated Integrin Av 35 Maintains A5 $\beta 1$-Dependent Desmoplastic Traits Prognostic of Neoplastic Recurrence. eLife 2017, 6. [CrossRef] [PubMed]

23. Tauriello, D.V.F.; Palomo-Ponce, S.; Stork, D.; Berenguer-Llergo, A.; Badia-Ramentol, J.; Iglesias, M.; Sevillano, M.; Ibiza, S.; Cañellas, A.; Hernando-Momblona, X.; et al. TGF $\beta$ Drives Immune Evasion in Genetically Reconstituted Colon Cancer Metastasis. Nature 2018, 554, 538-543. [CrossRef] [PubMed]

24. Barrett, R.L.; Puré, E. Cancer-Associated Fibroblasts and Their Influence on Tumor Immunity and Immunotherapy. eLife 2020, 9. [CrossRef] [PubMed]

25. Hida, K.; Maishi, N.; Annan, D.A.; Hida, Y. Contribution of Tumor Endothelial Cells in Cancer Progression. Int. J. Mol. Sci. 2018, 19, 1272. [CrossRef] [PubMed]

26. Döme, B.; Hendrix, M.J.C.; Paku, S.; Tóvári, J.; Tímár, J. Alternative Vascularization Mechanisms in Cancer: Pathology and Therapeutic Implications. Am. J. Pathol. 2007, 170, 1-15. [CrossRef]

27. Carmeliet, P.; Jain, R.K. Molecular Mechanisms and Clinical Applications of Angiogenesis. Nature 2011, 473, 298-307. [CrossRef]

28. Zhou, W.; Yang, L.; Nie, L.; Lin, H. Unraveling the Molecular Mechanisms between Inflammation and Tumor Angiogenesis. Am. J. Cancer Res. 2021, 11, 301-317.

29. Jain, R.K. Normalization of Tumor Vasculature: An Emerging Concept in Antiangiogenic Therapy. Science 2005, 307, 58-62. [CrossRef]

30. Italiani, P.; Boraschi, D. From Monocytes to M1/M2 Macrophages: Phenotypical vs. Functional Differentiation. Front. Immunol. 2014, 5, 514. [CrossRef] [PubMed]

31. Qian, B.-Z.; Pollard, J.W. Macrophage Diversity Enhances Tumor Progression and Metastasis. Cell 2010, $141,39-51$. [CrossRef] [PubMed]

32. Suva, L.J.; Washam, C.; Nicholas, R.W.; Griffin, R.J. Bone Metastasis: Mechanisms and Therapeutic Opportunities. Nat. Rev. Endocrinol. 2011, 7, 208-218. [CrossRef] [PubMed]

33. Ahmed, S.; Mohamed, H.T.; El-Husseiny, N.; El Mahdy, M.M.; Safwat, G.; Diab, A.A.; El-Sherif, A.A.; El-Shinawi, M.; Mohamed, M.M. IL-8 Secreted by Tumor Associated Macrophages Contribute to Lapatinib Resistance in HER2-Positive Locally Advanced Breast Cancer via Activation of Src/STAT3/ERK1/2-Mediated EGFR Signaling. Biochim. Biophys. Acta Mol. Cell Res. 2021, 1868, 118995. [CrossRef] [PubMed]

34. Lan, H.-R.; Du, W.-L.; Liu, Y.; Mao, C.-S.; Jin, K.-T.; Yang, X. Role of Immune Regulatory Cells in Breast Cancer: Foe or Friend? Int. Immunopharmacol. 2021, 96, 107627. [CrossRef] [PubMed]

35. Koukourakis, M.I.; Giatromanolaki, A.; Kakolyris, S.; O’Byrne, K.J.; Apostolikas, N.; Skarlatos, J.; Gatter, K.C.; Harris, A.L. Different Patterns of Stromal and Cancer Cell Thymidine Phosphorylase Reactivity in Non-Small-Cell Lung Cancer: Impact on Tumour Neoangiogenesis and Survival. Br. J. Cancer 1998, 77, 1696-1703. [CrossRef] [PubMed]

36. Dönmez, T.; Höhne, K.; Zissel, G.; Herrmann, K.; Hautzel, H.; Aigner, C.; Hegedüs, B.; Ploenes, T. Insights into Immunometabolism: A Dataset Correlating the 18FDG PET/CT Maximum Standard Uptake Value of the Primary Tumor with the CCL18 Serum Level in Non-Small Cell Lung Cancer. Data Brief 2021, 35, 106859. [CrossRef] [PubMed]

37. Dave, S.S.; Wright, G.; Tan, B.; Rosenwald, A.; Gascoyne, R.D.; Chan, W.C.; Fisher, R.I.; Braziel, R.M.; Rimsza, L.M.; Grogan, T.M.; et al. Prediction of Survival in Follicular Lymphoma Based on Molecular Features of Tumor-Infiltrating Immune Cells. N. Engl. J. Med. 2004, 351, 2159-2169. [CrossRef] [PubMed]

38. Bingle, L.; Brown, N.J.; Lewis, C.E. The Role of Tumour-Associated Macrophages in Tumour Progression: Implications for New Anticancer Therapies. J. Pathol. 2002, 196, 254-265. [CrossRef] [PubMed]

39. Mills, C.D.; Kincaid, K.; Alt, J.M.; Heilman, M.J.; Hill, A.M. M-1/M-2 Macrophages and the Th1/Th2 Paradigm. J. Immunol. 2000, 164, 6166-6173. [CrossRef]

40. Orecchioni, M.; Ghosheh, Y.; Pramod, A.B.; Ley, K. Macrophage Polarization: Different Gene Signatures in M1(LPS+) vs. Classically and M2(LPS-) vs. Alternatively Activated Macrophages. Front. Immunol. 2019, 10, 1084. [CrossRef] [PubMed]

41. Mosser, D.M.; Edwards, J.P. Exploring the Full Spectrum of Macrophage Activation. Nat. Rev. Immunol. 2008, 8, 958-969. [CrossRef] [PubMed]

42. Edwards, J.P.; Zhang, X.; Frauwirth, K.A.; Mosser, D.M. Biochemical and Functional Characterization of Three Activated Macrophage Populations. J. Leukoc. Biol. 2006, 80, 1298-1307. [CrossRef] [PubMed] 
43. Rőszer, T. Understanding the Mysterious M2 Macrophage through Activation Markers and Effector Mechanisms. Mediators Inflamm. 2015, 2015, 816460. [CrossRef] [PubMed]

44. Klimp, A.H.; de Vries, E.G.E.; Scherphof, G.L.; Daemen, T. A Potential Role of Macrophage Activation in the Treatment of Cancer. Crit. Rev. Oncol. Hematol. 2002, 44, 143-161. [CrossRef]

45. Swann, J.B.; Vesely, M.D.; Silva, A.; Sharkey, J.; Akira, S.; Schreiber, R.D.; Smyth, M.J. Demonstration of InflammationInduced Cancer and Cancer Immunoediting during Primary Tumorigenesis. Proc. Natl. Acad. Sci. USA 2008, 105, $652-656$. [CrossRef] [PubMed]

46. Mantovani, A.; Allavena, P.; Sica, A.; Balkwill, F. Cancer-Related Inflammation. Nature 2008, 454, 436-444. [CrossRef]

47. Masucci, M.T.; Minopoli, M.; Carriero, M.V. Tumor Associated Neutrophils. Their Role in Tumorigenesis, Metastasis, Prognosis and Therapy. Front. Oncol. 2019, 9, 1146. [CrossRef] [PubMed]

48. Shaul, M.E.; Fridlender, Z.G. Tumour-Associated Neutrophils in Patients with Cancer. Nat. Rev. Clin. Oncol. 2019, 16, 601-620. [CrossRef]

49. Powell, D.R.; Huttenlocher, A. Neutrophils in the Tumor Microenvironment. Trends Immunol. 2016, 37, 41-52. [CrossRef]

50. Giese, M.A.; Hind, L.E.; Huttenlocher, A. Neutrophil Plasticity in the Tumor Microenvironment. Blood 2019, 133, 2159-2167. [CrossRef]

51. Deryugina, E.I.; Zajac, E.; Juncker-Jensen, A.; Kupriyanova, T.A.; Welter, L.; Quigley, J.P. Tissue-Infiltrating Neutrophils Constitute the Major in Vivo Source of Angiogenesis-Inducing MMP-9 in the Tumor Microenvironment. Neoplasia 2014, 16, 771-788. [CrossRef]

52. Ostanin, D.V.; Kurmaeva, E.; Furr, K.; Bao, R.; Hoffman, J.; Berney, S.; Grisham, M.B. Acquisition of Antigen-Presenting Functions by Neutrophils Isolated from Mice with Chronic Colitis. J. Immunol. 2012, 188, 1491-1502. [CrossRef] [PubMed]

53. Puga, I.; Cols, M.; Barra, C.M.; He, B.; Cassis, L.; Gentile, M.; Comerma, L.; Chorny, A.; Shan, M.; Xu, W.; et al. B Cell-Helper Neutrophils Stimulate the Diversification and Production of Immunoglobulin in the Marginal Zone of the Spleen. Nat. Immunol. 2011, 13, 170-180. [CrossRef]

54. Pillay, J.; Kamp, V.M.; van Hoffen, E.; Visser, T.; Tak, T.; Lammers, J.-W.; Ulfman, L.H.; Leenen, L.P.; Pickkers, P.; Koenderman, L. A Subset of Neutrophils in Human Systemic Inflammation Inhibits T Cell Responses through Mac-1. J. Clin. Investig. 2012, 122, 327-336. [CrossRef] [PubMed]

55. Saini, M.; Szczerba, B.M.; Aceto, N. Circulating Tumor Cell-Neutrophil Tango along the Metastatic Process. Cancer Res. 2019, 79, 6067-6073. [CrossRef] [PubMed]

56. Sasaki, S.; Baba, T.; Muranaka, H.; Tanabe, Y.; Takahashi, C.; Matsugo, S.; Mukaida, N. Involvement of Prokineticin 2-Expressing Neutrophil Infiltration in 5-Fluorouracil-Induced Aggravation of Breast Cancer Metastasis to Lung. Mol. Cancer Ther. 2018, 17, 1515-1525. [CrossRef] [PubMed]

57. Teijeira, A.; Garasa, S.; Ochoa, M.C.; Villalba, M.; Olivera, I.; Cirella, A.; Eguren-Santamaria, I.; Berraondo, P.; Schalper, K.A.; de Andrea, C.E.; et al. IL8, Neutrophils, and NETs in a Collusion against Cancer Immunity and Immunotherapy. Clin. Cancer Res. Off. J. Am. Assoc. Cancer Res. 2020. [CrossRef]

58. Teijeira, Á.; Garasa, S.; Gato, M.; Alfaro, C.; Migueliz, I.; Cirella, A.; de Andrea, C.; Ochoa, M.C.; Otano, I.; Etxeberria, I.; et al. CXCR1 and CXCR2 Chemokine Receptor Agonists Produced by Tumors Induce Neutrophil Extracellular Traps That Interfere with Immune Cytotoxicity. Immunity 2020, 52, 856-871.e8. [CrossRef] [PubMed]

59. Schauer, C.; Janko, C.; Munoz, L.E.; Zhao, Y.; Kienhöfer, D.; Frey, B.; Lell, M.; Manger, B.; Rech, J.; Naschberger, E.; et al. Aggregated Neutrophil Extracellular Traps Limit Inflammation by Degrading Cytokines and Chemokines. Nat. Med. 2014, 20, 511-517. [CrossRef]

60. Clemente, C.G.; Mihm, M.C.; Bufalino, R.; Zurrida, S.; Collini, P.; Cascinelli, N. Prognostic Value of Tumor Infiltrating Lymphocytes in the Vertical Growth Phase of Primary Cutaneous Melanoma. Cancer 1996, 77, 1303-1310. [CrossRef]

61. Mackensen, A.; Ferradini, L.; Carcelain, G.; Triebel, F.; Faure, F.; Viel, S.; Hercend, T. Evidence for in Situ Amplification of Cytotoxic T-Lymphocytes with Antitumor Activity in a Human Regressive Melanoma. Cancer Res. 1993, 53, $3569-3573$.

62. Mahmoud, S.M.A.; Paish, E.C.; Powe, D.G.; Macmillan, R.D.; Grainge, M.J.; Lee, A.H.S.; Ellis, I.O.; Green, A.R. Tumor-Infiltrating CD8+ Lymphocytes Predict Clinical Outcome in Breast Cancer. J. Clin. Oncol. Off. J. Am. Soc. Clin. Oncol. 2011, 29, 1949-1955. [CrossRef] [PubMed]

63. Teschendorff, A.E.; Gomez, S.; Arenas, A.; El-Ashry, D.; Schmidt, M.; Gehrmann, M.; Caldas, C. Improved Prognostic Classification of Breast Cancer Defined by Antagonistic Activation Patterns of Immune Response Pathway Modules. BMC Cancer 2010, 10, 604. [CrossRef]

64. Dahlin, A.M.; Henriksson, M.L.; Van Guelpen, B.; Stenling, R.; Oberg, A.; Rutegård, J.; Palmqvist, R. Colorectal Cancer Prognosis Depends on T-Cell Infiltration and Molecular Characteristics of the Tumor. Mod. Pathol. Off. J. U. S. Can. Acad. Pathol. Inc 2011, 24, 671-682. [CrossRef]

65. Mlecnik, B.; Bindea, G.; Angell, H.K.; Maby, P.; Angelova, M.; Tougeron, D.; Church, S.E.; Lafontaine, L.; Fischer, M.; Fredriksen, T.; et al. Integrative Analyses of Colorectal Cancer Show Immunoscore Is a Stronger Predictor of Patient Survival Than Microsatellite Instability. Immunity 2016, 44, 698-711. [CrossRef] [PubMed]

66. Pagès, F.; Kirilovsky, A.; Mlecnik, B.; Asslaber, M.; Tosolini, M.; Bindea, G.; Lagorce, C.; Wind, P.; Marliot, F.; Bruneval, P.; et al. In Situ Cytotoxic and Memory T Cells Predict Outcome in Patients with Early-Stage Colorectal Cancer. J. Clin. Oncol. Off. J. Am. Soc. Clin. Oncol. 2009, 27, 5944-5951. [CrossRef] 
67. Dieu-Nosjean, M.-C.; Antoine, M.; Danel, C.; Heudes, D.; Wislez, M.; Poulot, V.; Rabbe, N.; Laurans, L.; Tartour, E.; de Chaisemartin, L.; et al. Long-Term Survival for Patients with Non-Small-Cell Lung Cancer with Intratumoral Lymphoid Structures. J. Clin. Oncol. Off. J. Am. Soc. Clin. Oncol. 2008, 26, 4410-4417. [CrossRef] [PubMed]

68. Kawai, O.; Ishii, G.; Kubota, K.; Murata, Y.; Naito, Y.; Mizuno, T.; Aokage, K.; Saijo, N.; Nishiwaki, Y.; Gemma, A.; et al. Predominant Infiltration of Macrophages and CD8(+) T Cells in Cancer Nests Is a Significant Predictor of Survival in Stage IV Nonsmall Cell Lung Cancer. Cancer 2008, 113, 1387-1395. [CrossRef] [PubMed]

69. Nakano, S.; Iyama, K.; Ogawa, M.; Yoshioka, H.; Sado, Y.; Oohashi, T.; Ninomiya, Y. Differential Tissular Expression and Localization of Type IV Collagen Alpha1(IV), Alpha2(IV), Alpha5(IV), and Alpha6(IV) Chains and Their MRNA in Normal Breast and in Benign and Malignant Breast Tumors. Lab. Investig. J. Tech. Methods Pathol. 1999, 79, 281-292.

70. Wakabayashi, O.; Yamazaki, K.; Oizumi, S.; Hommura, F.; Kinoshita, I.; Ogura, S.; Dosaka-Akita, H.; Nishimura, M. CD4+ T Cells in Cancer Stroma, Not CD8+ T Cells in Cancer Cell Nests, Are Associated with Favorable Prognosis in Human Non-Small Cell Lung Cancers. Cancer Sci. 2003, 94, 1003-1009. [CrossRef]

71. Koreishi, A.F.; Saenz, A.J.; Persky, D.O.; Cui, H.; Moskowitz, A.; Moskowitz, C.H.; Teruya-Feldstein, J. The Role of Cytotoxic and Regulatory T Cells in Relapsed/Refractory Hodgkin Lymphoma. Appl. Immunohistochem. Mol. Morphol. AIMM 2010, 18, $206-211$. [CrossRef] [PubMed]

72. Tzankov, A.; Meier, C.; Hirschmann, P.; Went, P.; Pileri, S.A.; Dirnhofer, S. Correlation of High Numbers of Intratumoral FOXP3+ Regulatory T Cells with Improved Survival in Germinal Center-like Diffuse Large B-Cell Lymphoma, Follicular Lymphoma and Classical Hodgkin's Lymphoma. Haematologica 2008, 93, 193-200. [CrossRef]

73. Junttila, M.R.; de Sauvage, F.J. Influence of Tumour Micro-Environment Heterogeneity on Therapeutic Response. Nature 2013, 501, 346-354. [CrossRef]

74. Hodi, F.S.; O’Day, S.J.; McDermott, D.F.; Weber, R.W.; Sosman, J.A.; Haanen, J.B.; Gonzalez, R.; Robert, C.; Schadendorf, D.; Hassel, J.C.; et al. Improved Survival with Ipilimumab in Patients with Metastatic Melanoma. N. Engl. J. Med. 2010, 363, 711-723. [CrossRef] [PubMed]

75. Akinleye, A.; Rasool, Z. Immune Checkpoint Inhibitors of PD-L1 as Cancer Therapeutics. J. Hematol. Oncol. 2019, 12, 92. [CrossRef]

76. Wensveen, F.M.; Jelenčić, V.; Polić, B. NKG2D: A Master Regulator of Immune Cell Responsiveness. Front. Immunol. 2018, 9 , 441. [CrossRef]

77. Allez, M.; Tieng, V.; Nakazawa, A.; Treton, X.; Pacault, V.; Dulphy, N.; Caillat-Zucman, S.; Paul, P.; Gornet, J.-M.; Douay, C.; et al. CD4+NKG2D+ T Cells in Crohn's Disease Mediate Inflammatory and Cytotoxic Responses through MICA Interactions. Gastroenterology 2007, 132, 2346-2358. [CrossRef]

78. Raulet, D.H.; Gasser, S.; Gowen, B.G.; Deng, W.; Jung, H. Regulation of Ligands for the NKG2D Activating Receptor. Annu. Rev. Immunol. 2013, 31, 413-441. [CrossRef]

79. Le Bert, N.; Gasser, S. Advances in NKG2D Ligand Recognition and Responses by NK Cells. Immunol. Cell Biol. 2014, 92, 230-236. [CrossRef] [PubMed]

80. Coronella, J.A.; Telleman, P.; Kingsbury, G.A.; Truong, T.D.; Hays, S.; Junghans, R.P. Evidence for an Antigen-Driven Humoral Immune Response in Medullary Ductal Breast Cancer. Cancer Res. 2001, 61, 7889-7899.

81. Milne, K.; Köbel, M.; Kalloger, S.E.; Barnes, R.O.; Gao, D.; Gilks, C.B.; Watson, P.H.; Nelson, B.H. Systematic Analysis of Immune Infiltrates in High-Grade Serous Ovarian Cancer Reveals CD20, FoxP3 and TIA-1 as Positive Prognostic Factors. PLoS ONE 2009, 4, e6412. [CrossRef]

82. Qin, Z.; Richter, G.; Schüler, T.; Ibe, S.; Cao, X.; Blankenstein, T. B Cells Inhibit Induction of T Cell-Dependent Tumor Immunity. Nat. Med. 1998, 4, 627-630. [CrossRef]

83. Andreu, P.; Johansson, M.; Affara, N.I.; Pucci, F.; Tan, T.; Junankar, S.; Korets, L.; Lam, J.; Tawfik, D.; DeNardo, D.G.; et al FcRgamma Activation Regulates Inflammation-Associated Squamous Carcinogenesis. Cancer Cell 2010, 17, 121-134. [CrossRef]

84. de Visser, K.E.; Korets, L.V.; Coussens, L.M. De Novo Carcinogenesis Promoted by Chronic Inflammation Is B Lymphocyte Dependent. Cancer Cell 2005, 7, 411-423. [CrossRef]

85. Schioppa, T.; Moore, R.; Thompson, R.G.; Rosser, E.C.; Kulbe, H.; Nedospasov, S.; Mauri, C.; Coussens, L.M.; Balkwill, F.R. B Regulatory Cells and the Tumor-Promoting Actions of TNF- $\alpha$ during Squamous Carcinogenesis. Proc. Natl. Acad. Sci. USA 2011, 108, 10662-10667. [CrossRef]

86. Sharonov, G.V.; Serebrovskaya, E.O.; Yuzhakova, D.V.; Britanova, O.V.; Chudakov, D.M. B Cells, Plasma Cells and Antibody Repertoires in the Tumour Microenvironment. Nat. Rev. Immunol. 2020, 20, 294-307. [CrossRef] [PubMed]

87. Artis, D.; Spits, H. The Biology of Innate Lymphoid Cells. Nature 2015, 517, 293-301. [CrossRef] [PubMed]

88. Simoni, Y.; Newell, E.W. Dissecting Human ILC Heterogeneity: More than Just Three Subsets. Immunology 2018, 153, 297-303. [CrossRef] [PubMed]

89. Bal, S.M.; Golebski, K.; Spits, H. Plasticity of Innate Lymphoid Cell Subsets. Nat. Rev. Immunol. 2020, 20, 552-565. [CrossRef]

90. Li, J.; Doty, A.L.; Tang, Y.; Berrie, D.; Iqbal, A.; Tan, S.A.; Clare-Salzler, M.J.; Wallet, S.M.; Glover, S.C. Enrichment of IL-17A+ IFN- $\Gamma+$ and IL-22+ IFN- $\Gamma+$ T Cell Subsets Is Associated with Reduction of NKp44+ ILC3s in the Terminal Ileum of Crohn's Disease Patients. Clin. Exp. Immunol. 2017, 190, 143-153. [CrossRef]

91. Cohen, I. DNA Damage Talks to Inflammation. Cytokine Growth Factor Rev. 2017, 33, 35-39. [CrossRef] [PubMed] 
92. Cui, J.; Shin, T.; Kawano, T.; Sato, H.; Kondo, E.; Toura, I.; Kaneko, Y.; Koseki, H.; Kanno, M.; Taniguchi, M. Requirement for Valpha14 NKT Cells in IL-12-Mediated Rejection of Tumors. Science 1997, 278, 1623-1626. [CrossRef] [PubMed]

93. Kawano, T.; Nakayama, T.; Kamada, N.; Kaneko, Y.; Harada, M.; Ogura, N.; Akutsu, Y.; Motohashi, S.; Iizasa, T.; Endo, H.; et al. Antitumor Cytotoxicity Mediated by Ligand-Activated Human V Alpha24 NKT Cells. Cancer Res. 1999, 59, 5102-5105. [PubMed]

94. Smyth, M.J.; Thia, K.Y.; Street, S.E.; Cretney, E.; Trapani, J.A.; Taniguchi, M.; Kawano, T.; Pelikan, S.B.; Crowe, N.Y.; Godfrey, D.I. Differential Tumor Surveillance by Natural Killer (NK) and NKT Cells. J. Exp. Med. 2000, 191, 661-668. [CrossRef]

95. Tachibana, T.; Onodera, H.; Tsuruyama, T.; Mori, A.; Nagayama, S.; Hiai, H.; Imamura, M. Increased Intratumor Valpha24-Positive Natural Killer T Cells: A Prognostic Factor for Primary Colorectal Carcinomas. Clin. Cancer Res. Off. J. Am. Assoc. Cancer Res. 2005, 11, 7322-7327. [CrossRef]

96. Terabe, M.; Matsui, S.; Noben-Trauth, N.; Chen, H.; Watson, C.; Donaldson, D.D.; Carbone, D.P.; Paul, W.E.; Berzofsky, J.A. NKT Cell-Mediated Repression of Tumor Immunosurveillance by IL-13 and the IL-4R-STAT6 Pathway. Nat. Immunol. 2000, 1, 515-520. [CrossRef]

97. Meredith, M.M.; Liu, K.; Darrasse-Jeze, G.; Kamphorst, A.O.; Schreiber, H.A.; Guermonprez, P.; Idoyaga, J.; Cheong, C.; Yao, K.-H.; Niec, R.E.; et al. Expression of the Zinc Finger Transcription Factor ZDC (Zbtb46, Btbd4) Defines the Classical Dendritic Cell Lineage. J. Exp. Med. 2012, 209, 1153-1165. [CrossRef] [PubMed]

98. Trovato, R.; Fiore, A.; Sartori, S.; Canè, S.; Giugno, R.; Cascione, L.; Paiella, S.; Salvia, R.; De Sanctis, F.; Poffe, O.; et al. Immunosuppression by Monocytic Myeloid-Derived Suppressor Cells in Patients with Pancreatic Ductal Carcinoma Is Orchestrated by STAT3. J. Immunother. Cancer 2019, 7, 255. [CrossRef]

99. Kumar, V.; Patel, S.; Tcyganov, E.; Gabrilovich, D.I. The Nature of Myeloid-Derived Suppressor Cells in the Tumor Microenvironment. Trends Immunol. 2016, 37, 208-220. [CrossRef]

100. Salemme, V.; Centonze, G.; Cavallo, F.; Defilippi, P.; Conti, L. The Crosstalk Between Tumor Cells and the Immune Microenvironment in Breast Cancer: Implications for Immunotherapy. Front. Oncol. 2021, 11, 610303. [CrossRef]

101. McAndrew, N.; DeMichele, A. Neoadjuvant Chemotherapy Considerations in Triple-Negative Breast Cancer. J. Target. Ther. Cancer 2018, 7, 52-69.

102. Gentles, A.J.; Hui, A.B.-Y.; Feng, W.; Azizi, A.; Nair, R.V.; Bouchard, G.; Knowles, D.A.; Yu, A.; Jeong, Y.; Bejnood, A.; et al. A Human Lung Tumor Microenvironment Interactome Identifies Clinically Relevant Cell-Type Cross-Talk. Genome Biol. 2020, 21, 107. [CrossRef]

103. Sarode, P.; Schaefer, M.B.; Grimminger, F.; Seeger, W.; Savai, R. Macrophage and Tumor Cell Cross-Talk Is Fundamental for Lung Tumor Progression: We Need to Talk. Front. Oncol. 2020, 10, 324. [CrossRef]

104. Galindo-Pumariño, C.; Collado, M.; Herrera, M.; Peña, C. Tumor Microenvironment in Metastatic Colorectal Cancer: The Arbitrator in Patients' Outcome. Cancers 2021, 13, 1130. [CrossRef]

105. Wei, C.; Yang, C.; Wang, S.; Shi, D.; Zhang, C.; Lin, X.; Liu, Q.; Dou, R.; Xiong, B. Crosstalk between Cancer Cells and Tumor Associated Macrophages Is Required for Mesenchymal Circulating Tumor Cell-Mediated Colorectal Cancer Metastasis. Mol. Cancer 2019, 18, 64. [CrossRef]

106. Mezzasoma, L.; Costanzi, E.; Scarpelli, P.; Talesa, V.N.; Bellezza, I. Extracellular Vesicles from Human Advanced-Stage Prostate Cancer Cells Modify the Inflammatory Response of Microenvironment-Residing Cells. Cancers 2019, 11, 1276. [CrossRef]

107. Elia, A.R.; Caputo, S.; Bellone, M. Immune Checkpoint-Mediated Interactions Between Cancer and Immune Cells in Prostate Adenocarcinoma and Melanoma. Front. Immunol. 2018, 9, 1786. [CrossRef] [PubMed]

108. Yeo, E.C.F.; Brown, M.P.; Gargett, T.; Ebert, L.M. The Role of Cytokines and Chemokines in Shaping the Immune Microenvironment of Glioblastoma: Implications for Immunotherapy. Cells 2021, 10, 607. [CrossRef] [PubMed]

109. Grégoire, H.; Roncali, L.; Rousseau, A.; Chérel, M.; Delneste, Y.; Jeannin, P.; Hindré, F.; Garcion, E. Targeting Tumor Associated Macrophages to Overcome Conventional Treatment Resistance in Glioblastoma. Front. Pharmacol. 2020, 11, 368. [CrossRef] [PubMed]

110. Bonnans, C.; Chou, J.; Werb, Z. Remodelling the Extracellular Matrix in Development and Disease. Nat. Rev. Mol. Cell Biol. 2014, 15, 786-801. [CrossRef] [PubMed]

111. Valkenburg, K.C.; de Groot, A.E.; Pienta, K.J. Targeting the Tumour Stroma to Improve Cancer Therapy. Nat. Rev. Clin. Oncol. 2018, 15, 366-381. [CrossRef]

112. Hynes, R.O. The Extracellular Matrix: Not Just Pretty Fibrils. Science 2009, 326, 1216-1219. [CrossRef]

113. Gehler, S.; Baldassarre, M.; Lad, Y.; Leight, J.L.; Wozniak, M.A.; Riching, K.M.; Eliceiri, K.W.; Weaver, V.M.; Calderwood, D.A.; Keely, P.J. Filamin A-Beta1 Integrin Complex Tunes Epithelial Cell Response to Matrix Tension. Mol. Biol. Cell 2009, 20, 3224-3238. [CrossRef]

114. Lopez, J.I.; Mouw, J.K.; Weaver, V.M. Biomechanical Regulation of Cell Orientation and Fate. Oncogene 2008, 27, 6981-6993. [CrossRef]

115. Paszek, M.J.; Zahir, N.; Johnson, K.R.; Lakins, J.N.; Rozenberg, G.I.; Gefen, A.; Reinhart-King, C.A.; Margulies, S.S.; Dembo, M.; Boettiger, D.; et al. Tensional Homeostasis and the Malignant Phenotype. Cancer Cell 2005, 8, 241-254. [CrossRef] [PubMed]

116. Lu, P.; Weaver, V.M.; Werb, Z. The Extracellular Matrix: A Dynamic Niche in Cancer Progression. J. Cell Biol. 2012, 196, 395-406. [CrossRef]

117. Cox, T.R.; Erler, J.T. Remodeling and Homeostasis of the Extracellular Matrix: Implications for Fibrotic Diseases and Cancer. Dis. Model. Mech. 2011, 4, 165-178. [CrossRef] 
118. Kass, L.; Erler, J.T.; Dembo, M.; Weaver, V.M. Mammary Epithelial Cell: Influence of Extracellular Matrix Composition and Organization during Development and Tumorigenesis. Int. J. Biochem. Cell Biol. 2007, 39, 1987-1994. [CrossRef]

119. Levental, K.R.; Yu, H.; Kass, L.; Lakins, J.N.; Egeblad, M.; Erler, J.T.; Fong, S.F.T.; Csiszar, K.; Giaccia, A.; Weninger, W.; et al. Matrix Crosslinking Forces Tumor Progression by Enhancing Integrin Signaling. Cell 2009, 139, 891-906. [CrossRef] [PubMed]

120. Ilan, N.; Elkin, M.; Vlodavsky, I. Regulation, Function and Clinical Significance of Heparanase in Cancer Metastasis and Angiogenesis. Int. J. Biochem. Cell Biol. 2006, 38, 2018-2039. [CrossRef] [PubMed]

121. Kessenbrock, K.; Plaks, V.; Werb, Z. Matrix Metalloproteinases: Regulators of the Tumor Microenvironment. Cell 2010, 141 , 52-67. [CrossRef] [PubMed]

122. Li, L.; Xie, T. Stem Cell Niche: Structure and Function. Annu. Rev. Cell Dev. Biol. 2005, 21, 605-631. [CrossRef]

123. Hanahan, D.; Weinberg, R.A. Hallmarks of Cancer: The next Generation. Cell 2011, 144, 646-674. [CrossRef] [PubMed]

124. Landskron, G.; De la Fuente, M.; Thuwajit, P.; Thuwajit, C.; Hermoso, M.A. Chronic Inflammation and Cytokines in the Tumor Microenvironment. J. Immunol. Res. 2014, 2014, 149185. [CrossRef] [PubMed]

125. Aggarwal, B.B.; Gehlot, P. Inflammation and Cancer: How Friendly Is the Relationship for Cancer Patients? Curr. Opin. Pharmacol. 2009, 9, 351-369. [CrossRef]

126. Feagins, L.A.; Souza, R.F.; Spechler, S.J. Carcinogenesis in IBD: Potential Targets for the Prevention of Colorectal Cancer. Nat. Rev. Gastroenterol. Hepatol. 2009, 6, 297-305. [CrossRef]

127. Kawanishi, S.; Hiraku, Y.; Pinlaor, S.; Ma, N. Oxidative and Nitrative DNA Damage in Animals and Patients with Inflammatory Diseases in Relation to Inflammation-Related Carcinogenesis. Biol. Chem. 2006, 387, 365-372. [CrossRef]

128. Murata, M.; Thanan, R.; Ma, N.; Kawanishi, S. Role of Nitrative and Oxidative DNA Damage in Inflammation-Related Carcinogenesis. J. Biomed. Biotechnol. 2012, 2012, 623019. [CrossRef]

129. Canavan, C.; Abrams, K.R.; Mayberry, J. Meta-Analysis: Colorectal and Small Bowel Cancer Risk in Patients with Crohn's Disease. Aliment. Pharmacol. Ther. 2006, 23, 1097-1104. [CrossRef] [PubMed]

130. Eaden, J.A.; Abrams, K.R.; Mayberry, J.F. The Risk of Colorectal Cancer in Ulcerative Colitis: A Meta-Analysis. Gut 2001, 48, 526-535. [CrossRef]

131. Jess, T.; Loftus, E.V.; Velayos, F.S.; Harmsen, W.S.; Zinsmeister, A.R.; Smyrk, T.C.; Schleck, C.D.; Tremaine, W.J.; Melton, L.J.; Munkholm, P.; et al. Risk of Intestinal Cancer in Inflammatory Bowel Disease: A Population-Based Study from Olmsted County, Minnesota. Gastroenterology 2006, 130, 1039-1046. [CrossRef] [PubMed]

132. Vainio, H.; Boffetta, P. Mechanisms of the Combined Effect of Asbestos and Smoking in the Etiology of Lung Cancer. Scand. J. Work. Environ. Health 1994, 20, 235-242. [CrossRef] [PubMed]

133. Yoshida, T.; Kato, J.; Inoue, I.; Yoshimura, N.; Deguchi, H.; Mukoubayashi, C.; Oka, M.; Watanabe, M.; Enomoto, S.; Niwa, T.; et al. Cancer Development Based on Chronic Active Gastritis and Resulting Gastric Atrophy as Assessed by Serum Levels of Pepsinogen and Helicobacter Pylori Antibody Titer. Int. J. Cancer 2014, 134, 1445-1457. [CrossRef] [PubMed]

134. Krieger, J.N.; Riley, D.E.; Vesella, R.L.; Miner, D.C.; Ross, S.O.; Lange, P.H. Bacterial Dna Sequences in Prostate Tissue from Patients with Prostate Cancer and Chronic Prostatitis. J. Urol. 2000, 164, 1221-1228. [CrossRef]

135. El-Serag, H.B. Epidemiology of Viral Hepatitis and Hepatocellular Carcinoma. Gastroenterology 2012, 142, $1264-1273 . e 1$. [CrossRef] [PubMed]

136. Araldi, R.P.; Sant'Ana, T.A.; Módolo, D.G.; de Melo, T.C.; Spadacci-Morena, D.D.; de Cassia Stocco, R.; Cerutti, J.M.; de Souza, E.B. The Human Papillomavirus (HPV)-Related Cancer Biology: An Overview. Biomed. Pharmacother. 2018, 106, 1537-1556. [CrossRef]

137. Lekakos, L.; Karidis, N.P.; Dimitroulis, D.; Tsigris, C.; Kouraklis, G.; Nikiteas, N. Barrett's Esophagus with High-Grade Dysplasia: Focus on Current Treatment Options. World J. Gastroenterol. 2011, 17, 4174-4183. [CrossRef] [PubMed]

138. Zabron, A.; Edwards, R.J.; Khan, S.A. The Challenge of Cholangiocarcinoma: Dissecting the Molecular Mechanisms of an Insidious Cancer. Dis. Model. Mech. 2013, 6, 281-292. [CrossRef]

139. Singh, R.K.; Gutman, M.; Reich, R.; Bar-Eli, M. Ultraviolet B Irradiation Promotes Tumorigenic and Metastatic Properties in Primary Cutaneous Melanoma via Induction of Interleukin 8. Cancer Res. 1995, 55, 3669-3674. [CrossRef]

140. Bats, A.S.; Zafrani, Y.; Pautier, P.; Duvillard, P.; Morice, P. Malignant Transformation of Abdominal Wall Endometriosis to Clear Cell Carcinoma: Case Report and Review of the Literature. Fertil. Steril. 2008, 90, 1197.e13-1197.e16. [CrossRef]

141. Levin, B. Gallbladder Carcinoma. Ann. Oncol. Off. J. Eur. Soc. Med. Oncol. 1999, 10 (Suppl. 4), 129-130. [CrossRef]

142. Turner, M.D.; Nedjai, B.; Hurst, T.; Pennington, D.J. Cytokines and Chemokines: At the Crossroads of Cell Signalling and Inflammatory Disease. Biochim. Biophys. Acta 2014, 1843, 2563-2582. [CrossRef]

143. Dinarello, C.A. The Paradox of Pro-Inflammatory Cytokines in Cancer. Cancer Metastasis Rev. 2006, 25, 307-313. [CrossRef] [PubMed]

144. Colotta, F.; Allavena, P.; Sica, A.; Garlanda, C.; Mantovani, A. Cancer-Related Inflammation, the Seventh Hallmark of Cancer: Links to Genetic Instability. Carcinogenesis 2009, 30, 1073-1081. [CrossRef] [PubMed]

145. Schenk, M.; Fabri, M.; Krutzik, S.R.; Lee, D.J.; Vu, D.M.; Sieling, P.A.; Montoya, D.; Liu, P.T.; Modlin, R.L. Interleukin-1 $\beta$ Triggers the Differentiation of Macrophages with Enhanced Capacity to Present Mycobacterial Antigen to T Cells. Immunology 2014, 141, 174-180. [CrossRef]

146. Apte, R.N.; Krelin, Y.; Song, X.; Dotan, S.; Recih, E.; Elkabets, M.; Carmi, Y.; Dvorkin, T.; White, R.M.; Gayvoronsky, L.; et al. Effects of Micro-Environment- and Malignant Cell-Derived Interleukin-1 in Carcinogenesis, Tumour Invasiveness and Tumour-Host Interactions. Eur. J. Cancer Oxf. Engl. 1990 2006, 42, 751-759. [CrossRef] 
147. Gelfo, V.; Romaniello, D.; Mazzeschi, M.; Sgarzi, M.; Grilli, G.; Morselli, A.; Manzan, B.; Rihawi, K.; Lauriola, M. Roles of IL-1 in Cancer: From Tumor Progression to Resistance to Targeted Therapies. Int. J. Mol. Sci. 2020, 21, 9. [CrossRef]

148. Voronov, E.; Apte, R.N. IL-1 in Colon Inflammation, Colon Carcinogenesis and Invasiveness of Colon Cancer. Cancer Microenviron. Off. J. Int. Cancer Microenviron. Soc. 2015, 8, 187-200. [CrossRef] [PubMed]

149. Oh, K.; Lee, O.-Y.; Park, Y.; Seo, M.W.; Lee, D.-S. IL-1 $\beta$ Induces IL-6 Production and Increases Invasiveness and EstrogenIndependent Growth in a TG2-Dependent Manner in Human Breast Cancer Cells. BMC Cancer 2016, 16, 724. [CrossRef]

150. Terzić, J.; Grivennikov, S.; Karin, E.; Karin, M. Inflammation and Colon Cancer. Gastroenterology 2010, 138, 2101-2114.e5. [CrossRef]

151. Akagi, Y.; Liu, W.; Xie, K.; Zebrowski, B.; Shaheen, R.M.; Ellis, L.M. Regulation of Vascular Endothelial Growth Factor Expression in Human Colon Cancer by Interleukin-1beta. Br. J. Cancer 1999, 80, 1506-1511. [CrossRef]

152. Carmi, Y.; Dotan, S.; Rider, P.; Kaplanov, I.; White, M.R.; Baron, R.; Abutbul, S.; Huszar, M.; Dinarello, C.A.; Apte, R.N.; et al. The Role of IL-1 $\beta$ in the Early Tumor Cell-Induced Angiogenic Response. J. Immunol. 2013, 190, 3500-3509. [CrossRef]

153. Baker, K.J.; Houston, A.; Brint, E. IL-1 Family Members in Cancer; Two Sides to Every Story. Front. Immunol. 2019, 10, 1197. [CrossRef]

154. Lewis, A.M.; Varghese, S.; Xu, H.; Alexander, H.R. Interleukin-1 and Cancer Progression: The Emerging Role of Interleukin-1 Receptor Antagonist as a Novel Therapeutic Agent in Cancer Treatment. J. Transl. Med. 2006, 4, 48. [CrossRef] [PubMed]

155. Kitamura, H.; Ohno, Y.; Toyoshima, Y.; Ohtake, J.; Homma, S.; Kawamura, H.; Takahashi, N.; Taketomi, A. Interleukin6/STAT3 Signaling as a Promising Target to Improve the Efficacy of Cancer Immunotherapy. Cancer Sci. 2017, 108, 1947-1952. [CrossRef] [PubMed]

156. Kumari, N.; Dwarakanath, B.S.; Das, A.; Bhatt, A.N. Role of Interleukin-6 in Cancer Progression and Therapeutic Resistance. Tumour Biol. J. Int. Soc. Oncodev. Biol. Med. 2016, 37, 11553-11572. [CrossRef] [PubMed]

157. Rossi, J.-F.; Lu, Z.-Y.; Jourdan, M.; Klein, B. Interleukin-6 as a Therapeutic Target. Clin. Cancer Res. Off. J. Am. Assoc. Cancer Res. 2015, 21, 1248-1257. [CrossRef] [PubMed]

158. Nagasaki, T.; Hara, M.; Nakanishi, H.; Takahashi, H.; Sato, M.; Takeyama, H. Interleukin-6 Released by Colon Cancer-Associated Fibroblasts Is Critical for Tumour Angiogenesis: Anti-Interleukin-6 Receptor Antibody Suppressed Angiogenesis and Inhibited Tumour-Stroma Interaction. Br. J. Cancer 2014, 110, 469-478. [CrossRef]

159. Gough, P.; Myles, I.A. Tumor Necrosis Factor Receptors: Pleiotropic Signaling Complexes and Their Differential Effects. Front. Immunol. 2020, 11, 585880. [CrossRef] [PubMed]

160. Micheau, O.; Tschopp, J. Induction of TNF Receptor I-Mediated Apoptosis via Two Sequential Signaling Complexes. Cell 2003, 114, 181-190. [CrossRef]

161. Fakhoury, M.; Negrulj, R.; Mooranian, A.; Al-Salami, H. Inflammatory Bowel Disease: Clinical Aspects and Treatments. J. Inflamm. Res. 2014, 7, 113-120. [CrossRef]

162. Pereira, R.; Faria, R.; Lago, P.; Torres, T. Infection and Malignancy Risk in Patients Treated with TNF Inhibitors for ImmuneMediated Inflammatory Diseases. Curr. Drug Saf. 2017, 12, 162-170. [CrossRef]

163. Nagarsheth, N.; Wicha, M.S.; Zou, W. Chemokines in the Cancer Microenvironment and Their Relevance in Cancer Immunotherapy. Nat. Rev. Immunol. 2017, 17, 559-572. [CrossRef] [PubMed]

164. Waugh, D.J.J.; Wilson, C. The Interleukin-8 Pathway in Cancer. Clin. Cancer Res. Off. J. Am. Assoc. Cancer Res. 2008, $14,6735-6741$. [CrossRef] [PubMed]

165. Bikfalvi, A.; Billottet, C. The CC and CXC Chemokines: Major Regulators of Tumor Progression and the Tumor Microenvironment. Am. J. Physiol. Cell Physiol. 2020, 318, C542-C554. [CrossRef] [PubMed]

166. Wang, L.; Kuang, Z.; Zhang, D.; Gao, Y.; Ying, M.; Wang, T. Reactive Oxygen Species in Immune Cells: A New Antitumor Target. Biomed. Pharmacother. 2021, 133, 110978. [CrossRef]

167. Moore, K.W.; de Waal Malefyt, R.; Coffman, R.L.; O'Garra, A. Interleukin-10 and the Interleukin-10 Receptor. Annu. Rev. Immunol. 2001, 19, 683-765. [CrossRef]

168. Zhu, L.; Shi, T.; Zhong, C.; Wang, Y.; Chang, M.; Liu, X. IL-10 and IL-10 Receptor Mutations in Very Early Onset Inflammatory Bowel Disease. Gastroenterol. Res. 2017, 10, 65-69. [CrossRef]

169. Franke, A.; McGovern, D.P.B.; Barrett, J.C.; Wang, K.; Radford-Smith, G.L.; Ahmad, T.; Lees, C.W.; Balschun, T.; Lee, J.; Roberts, R.; et al. Genome-Wide Meta-Analysis Increases to 71 the Number of Confirmed Crohn's Disease Susceptibility Loci. Nat. Genet. 2010, 42, 1118-1125. [CrossRef] [PubMed]

170. Shouval, D.S.; Biswas, A.; Goettel, J.A.; McCann, K.; Conaway, E.; Redhu, N.S.; Mascanfroni, I.D.; Al Adham, Z.; Lavoie, S.; Ibourk, M.; et al. Interleukin-10 Receptor Signaling in Innate Immune Cells Regulates Mucosal Immune Tolerance and Anti-Inflammatory Macrophage Function. Immunity 2014, 40, 706-719. [CrossRef]

171. Coperchini, F.; Chiovato, L.; Ricci, G.; Croce, L.; Magri, F.; Rotondi, M. The Cytokine Storm in COVID-19: Further Advances in Our Understanding the Role of Specific Chemokines Involved. Cytokine Growth Factor Rev. 2021, 58, 82-91. [CrossRef]

172. Rossi, J.-F.; Lu, Z.Y.; Massart, C.; Levon, K. Dynamic Immune/Inflammation Precision Medicine: The Good and the Bad Inflammation in Infection and Cancer. Front. Immunol. 2021, 12, 595722. [CrossRef] [PubMed]

173. Cobb, D.A.; Lee, D.W. Cytokine Release Syndrome Biology and Management. Cancer J. Sudbury Mass 2021, 27, 119-125. [CrossRef]

174. Oft, M. IL-10: Master Switch from Tumor-Promoting Inflammation to Antitumor Immunity. Cancer Immunol. Res. 2014, 2, 194-199. [CrossRef]

175. Massagué, J. TGFbeta in Cancer. Cell 2008, 134, 215-230. [CrossRef] 
176. Gonzalez, H.; Hagerling, C.; Werb, Z. Roles of the Immune System in Cancer: From Tumor Initiation to Metastatic Progression. Genes Dev. 2018, 32, 1267-1284. [CrossRef]

177. Itatani, Y.; Kawada, K.; Sakai, Y. Transforming Growth Factor- $\beta$ Signaling Pathway in Colorectal Cancer and Its Tumor Microenvironment. Int. J. Mol. Sci. 2019, 20, 5822. [CrossRef]

178. Derynck, R.; Turley, S.J.; Akhurst, R.J. TGF $\beta$ Biology in Cancer Progression and Immunotherapy. Nat. Rev. Clin. Oncol. 2021, 18, 9-34. [CrossRef]

179. Coricello, A.; Mesiti, F.; Lupia, A.; Maruca, A.; Alcaro, S. Inside Perspective of the Synthetic and Computational Toolbox of JAK Inhibitors: Recent Updates. Mol. Basel Switz. 2020, 25, 3321. [CrossRef]

180. Guanizo, A.C.; Fernando, C.D.; Garama, D.J.; Gough, D.J. STAT3: A Multifaceted Oncoprotein. Growth Factors Chur Switz. 2018, 36, 1-14. [CrossRef]

181. Ji, Z.; He, L.; Regev, A.; Struhl, K. Inflammatory Regulatory Network Mediated by the Joint Action of NF-KB, STAT3, and AP-1 Factors Is Involved in Many Human Cancers. Proc. Natl. Acad. Sci. USA 2019, 116, 9453-9462. [CrossRef]

182. Fu, L.-Q.; Du, W.-L.; Cai, M.-H.; Yao, J.-Y.; Zhao, Y.-Y.; Mou, X.-Z. The Roles of Tumor-Associated Macrophages in Tumor Angiogenesis and Metastasis. Cell. Immunol. 2020, 353, 104119. [CrossRef]

183. Leng, K.; Xu, Y.; Kang, P.; Qin, W.; Cai, H.; Wang, H.; Ji, D.; Jiang, X.; Li, J.; Li, Z.; et al. Akirin2 Is Modulated by MiR-490-3p and Facilitates Angiogenesis in Cholangiocarcinoma through the IL-6/STAT3/VEGFA Signaling Pathway. Cell Death Dis. 2019, 10, 262. [CrossRef]

184. Yuan, S.; Zhang, S.; Zhuang, Y.; Zhang, H.; Bai, J.; Hou, Q. Interleukin-17 Stimulates STAT3-Mediated Endothelial Cell Activation for Neutrophil Recruitment. Cell. Physiol. Biochem. Int. J. Exp. Cell. Physiol. Biochem. Pharmacol. 2015, 36, 2340-2356. [CrossRef]

185. Wang, Y.; Chen, Q.; Zhang, Z.; Jiang, F.; Meng, X.; Yan, H. Interleukin-10 Overexpression Improves the Function of Endothelial Progenitor Cells Stimulated with TNF- $\alpha$ through the Activation of the STAT3 Signaling Pathway. Int. J. Mol. Med. 2015, 35, 471-477. [CrossRef]

186. Zhao, D.; Pan, C.; Sun, J.; Gilbert, C.; Drews-Elger, K.; Azzam, D.J.; Picon-Ruiz, M.; Kim, M.; Ullmer, W.; El-Ashry, D.; et al. VEGF Drives Cancer-Initiating Stem Cells through VEGFR-2/Stat3 Signaling to Upregulate Myc and Sox2. Oncogene 2015, 34, 3107-3119. [CrossRef]

187. Chen, L.; Han, X. Anti-PD-1/PD-L1 Therapy of Human Cancer: Past, Present, and Future. J. Clin. Investig. 2015, 125, 3384-3391. [CrossRef]

188. Bloom, M.J.; Saksena, S.D.; Swain, G.P.; Behar, M.S.; Yankeelov, T.E.; Sorace, A.G. The Effects of IKK-Beta Inhibition on Early NF-Kappa-B Activation and Transcription of Downstream Genes. Cell. Signal. 2019, 55, 17-25. [CrossRef]

189. Greten, F.R.; Eckmann, L.; Greten, T.F.; Park, J.M.; Li, Z.-W.; Egan, L.J.; Kagnoff, M.F.; Karin, M. IKKbeta Links Inflammation and Tumorigenesis in a Mouse Model of Colitis-Associated Cancer. Cell 2004, 118, 285-296. [CrossRef]

190. Karin, M.; Cao, Y.; Greten, F.R.; Li, Z.-W. NF-KappaB in Cancer: From Innocent Bystander to Major Culprit. Nat. Rev. Cancer 2002, 2, 301-310. [CrossRef]

191. Aggarwal, B.B. Nuclear Factor-KappaB: The Enemy Within. Cancer Cell 2004, 6, 203-208. [CrossRef]

192. Lalle, G.; Twardowski, J.; Grinberg-Bleyer, Y. NF-KB in Cancer Immunity: Friend or Foe? Cells 2021, 10, 355. [CrossRef]

193. Fan, Y.; Mao, R.; Yang, J. NF-KB and STAT3 Signaling Pathways Collaboratively Link Inflammation to Cancer. Protein Cell 2013, 4, 176-185. [CrossRef]

194. Taniguchi, K.; Karin, M. NF-KB, Inflammation, Immunity and Cancer: Coming of Age. Nat. Rev. Immunol. 2018, 18, 309-324. [CrossRef]

195. Papila, K.B.; Sozer, V.; Cigdem, K.P.; Durmus, S.; Kurtulus, D.; Papila, C.; Gelisgen, R.; Uzun, H. Circulating Nuclear Factor-Kappa B Mediates Cancer-Associated Inflammation in Human Breast and Colon Cancer. J. Med. Biochem. 2021, 40, 150-159. [CrossRef]

196. Dong, F.; Zhou, X.; Li, C.; Yan, S.; Deng, X.; Cao, Z.; Li, L.; Tang, B.; Allen, T.D.; Liu, J. Dihydroartemisinin Targets VEGFR2 via the NF-KB Pathway in Endothelial Cells to Inhibit Angiogenesis. Cancer Biol. Ther. 2014, 15, 1479-1488. [CrossRef]

197. Martin, D.; Galisteo, R.; Gutkind, J.S. CXCL8/IL8 Stimulates Vascular Endothelial Growth Factor (VEGF) Expression and the Autocrine Activation of VEGFR2 in Endothelial Cells by Activating NFkappaB through the CBM (Carma3/Bcl10/Malt1) Complex. J. Biol. Chem. 2009, 284, 6038-6042. [CrossRef]

198. Godwin, P.; Baird, A.M.; Heavey, S.; Barr, M.P.; O’Byrne, K.J.; Gately, K. Targeting Nuclear Factor-Kappa B to Overcome Resistance to Chemotherapy. Front. Oncol. 2013, 3, 120. [CrossRef]

199. De, D.; Chowdhury, P.; Panda, S.K.; Ghosh, U. Ethanolic Extract of Leaf of Dillenia Pentagyna Reduces In-Vitro Cell Migration and Induces Intrinsic Pathway of Apoptosis via Downregulation of NF-K $\beta$ in Human NSCLC A549 Cells. J. Cell. Biochem. 2019, 120, 19841-19857. [CrossRef]

200. Huang, L.; Jian, Z.; Gao, Y.; Zhou, P.; Zhang, G.; Jiang, B.; Lv, Y. RPN2 Promotes Metastasis of Hepatocellular Carcinoma Cell and Inhibits Autophagy via STAT3 and NF-KB Pathways. Aging 2019, 11, 6674-6690. [CrossRef]

201. Pu, D.; Yin, L.; Huang, L.; Qin, C.; Zhou, Y.; Wu, Q.; Li, Y.; Zhou, Q.; Li, L. Cyclooxygenase-2 Inhibitor: A Potential Combination Strategy With Immunotherapy in Cancer. Front. Oncol. 2021, 11, 637504. [CrossRef]

202. Wang, D.; Dubois, R.N. Eicosanoids and Cancer. Nat. Rev. Cancer 2010, 10, 181-193. [CrossRef]

203. Ferrer, M.D.; Busquets-Cortés, C.; Capó, X.; Tejada, S.; Tur, J.A.; Pons, A.; Sureda, A. Cyclooxygenase-2 Inhibitors as a Therapeutic Target in Inflammatory Diseases. Curr. Med. Chem. 2019, 26, 3225-3241. [CrossRef] 
204. Zelenay, S.; van der Veen, A.G.; Böttcher, J.P.; Snelgrove, K.J.; Rogers, N.; Acton, S.E.; Chakravarty, P.; Girotti, M.R.; Marais, R.; Quezada, S.A.; et al. Cyclooxygenase-Dependent Tumor Growth through Evasion of Immunity. Cell 2015, 162, 1257-1270. [CrossRef]

205. Pan, Q.; Bao, L.W.; Merajver, S.D. Tetrathiomolybdate Inhibits Angiogenesis and Metastasis through Suppression of the NFkappaB Signaling Cascade. Mol. Cancer Res. MCR 2003, 1, 701-706.

206. Wang, D.; DuBois, R.N. Immunosuppression Associated with Chronic Inflammation in the Tumor Microenvironment. Carcinogenesis 2015, 36, 1085-1093. [CrossRef] [PubMed]

207. Escuin-Ordinas, H.; Atefi, M.; Fu, Y.; Cass, A.; Ng, C.; Huang, R.R.; Yashar, S.; Comin-Anduix, B.; Avramis, E.; Cochran, A.J.; et al. COX-2 Inhibition Prevents the Appearance of Cutaneous Squamous Cell Carcinomas Accelerated by BRAF Inhibitors. Mol. Oncol. 2014, 8, 250-260. [CrossRef] [PubMed]

208. Panza, E.; De Cicco, P.; Ercolano, G.; Armogida, C.; Scognamiglio, G.; Anniciello, A.M.; Botti, G.; Cirino, G.; Ianaro, A. Differential Expression of Cyclooxygenase-2 in Metastatic Melanoma Affects Progression Free Survival. Oncotarget 2016, 7, 57077-57085. [CrossRef] [PubMed]

209. Miao, J.; Lu, X.; Hu, Y.; Piao, C.; Wu, X.; Liu, X.; Huang, C.; Wang, Y.; Li, D.; Liu, J. Prostaglandin E2 and PD-1 Mediated Inhibition of Antitumor CTL Responses in the Human Tumor Microenvironment. Oncotarget 2017, 8, 89802-89810. [CrossRef] [PubMed]

210. Gu, K.J.; Li, G. An Overview of Cancer Prevention: Chemoprevention and Immunoprevention. J. Cancer Prev. 2020, 25, 127-135. [CrossRef]

211. Markosyan, N.; Li, J.; Sun, Y.H.; Richman, L.P.; Lin, J.H.; Yan, F.; Quinones, L.; Sela, Y.; Yamazoe, T.; Gordon, N.; et al. Tumor Cell-Intrinsic EPHA2 Suppresses Anti-Tumor Immunity by Regulating PTGS2 (COX-2). J. Clin. Investig. 2019, 129, 3594-3609. [CrossRef]

212. Yan, G.; Zhao, H.; Zhang, Q.; Zhou, Y.; Wu, L.; Lei, J.; Wang, X.; Zhang, J.; Zhang, X.; Zheng, L.; et al. A RIPK3-PGE2 Circuit Mediates Myeloid-Derived Suppressor Cell-Potentiated Colorectal Carcinogenesis. Cancer Res. 2018, 78, 5586-5599. [CrossRef] [PubMed]

213. Li, A.; Chen, P.; Leng, Y.; Kang, J. Histone Deacetylase 6 Regulates the Immunosuppressive Properties of Cancer-Associated Fibroblasts in Breast Cancer through the STAT3-COX2-Dependent Pathway. Oncogene 2018, 37, 5952-5966. [CrossRef]

214. Chiang, K.-H.; Shieh, J.-M.; Shen, C.-J.; Chang, T.-W.; Wu, P.-T.; Hsu, J.-Y.; Tsai, J.-P.; Chang, W.-C.; Chen, B.-K. Epidermal Growth Factor-Induced COX-2 Regulates Metastasis of Head and Neck Squamous Cell Carcinoma through Upregulation of Angiopoietin-like 4. Cancer Sci. 2020, 111, 2004-2015. [CrossRef] [PubMed]

215. Smakman, N.; Kranenburg, O.; Vogten, J.M.; Bloemendaal, A.L.A.; van Diest, P.; Borel Rinkes, I.H.M. Cyclooxygenase-2 Is a Target of KRASD12, Which Facilitates the Outgrowth of Murine C26 Colorectal Liver Metastases. Clin. Cancer Res. Off. J. Am. Assoc. Cancer Res. 2005, 11, 41-48.

216. Lim, H.J.; Park, J.H.; Jo, C.; Yoon, K.; Koh, Y.H. Cigarette Smoke Extracts and Cadmium Induce COX-2 Expression through $\gamma$-Secretase-Mediated P38 MAPK Activation in C6 Astroglia Cells. PLoS ONE 2019, 14, e0212749. [CrossRef]

217. Tang, F.; Wang, Y.; Hemmings, B.A.; Rüegg, C.; Xue, G. PKB/Akt-Dependent Regulation of Inflammation in Cancer. Semin. Cancer Biol. 2018, 48, 62-69. [CrossRef]

218. Noorolyai, S.; Shajari, N.; Baghbani, E.; Sadreddini, S.; Baradaran, B. The Relation between PI3K/AKT Signalling Pathway and Cancer. Gene 2019, 698, 120-128. [CrossRef]

219. Xu, K.; Liu, P.; Wei, W. MTOR Signaling in Tumorigenesis. Biochim. Biophys. Acta 2014, 1846, 638-654. [CrossRef]

220. Tang, H.; Massi, D.; Hemmings, B.A.; Mandalà, M.; Hu, Z.; Wicki, A.; Xue, G. AKT-Ions with a TWIST between EMT and MET. Oncotarget 2016, 7, 62767-62777. [CrossRef]

221. Chen, Y.; Kijlstra, A.; Chen, Y.; Yang, P. IL-17A Stimulates the Production of Inflammatory Mediators via Erk1/2, P38 MAPK, PI3K/Akt, and NF-KB Pathways in ARPE-19 Cells. Mol. Vis. 2011, 17, 3072-3077.

222. Dan, H.C.; Cooper, M.J.; Cogswell, P.C.; Duncan, J.A.; Ting, J.P.-Y.; Baldwin, A.S. Akt-Dependent Regulation of NF-\{kappa\}B Is Controlled by MTOR and Raptor in Association with IKK. Genes Dev. 2008, 22, 1490-1500. [CrossRef] [PubMed]

223. Factor, V.; Oliver, A.L.; Panta, G.R.; Thorgeirsson, S.S.; Sonenshein, G.E.; Arsura, M. Roles of Akt/PKB and IKK Complex in Constitutive Induction of NF-KappaB in Hepatocellular Carcinomas of Transforming Growth Factor Alpha/c-Myc Transgenic Mice. Hepatol. Baltim. Md 2001, 34, 32-41. [CrossRef] [PubMed]

224. Gu, F.-M.; Li, Q.-L.; Gao, Q.; Jiang, J.-H.; Zhu, K.; Huang, X.-Y.; Pan, J.-F.; Yan, J.; Hu, J.-H.; Wang, Z.; et al. IL-17 Induces AKT-Dependent IL-6/JAK2/STAT3 Activation and Tumor Progression in Hepatocellular Carcinoma. Mol. Cancer 2011, 10, 150. [CrossRef]

225. Xue, G.; Zippelius, A.; Wicki, A.; Mandalà, M.; Tang, F.; Massi, D.; Hemmings, B.A. Integrated Akt/PKB Signaling in Immunomodulation and Its Potential Role in Cancer Immunotherapy. J. Natl. Cancer Inst. 2015, 107. [CrossRef]

226. Liu, L.-Z.; Hu, X.-W.; Xia, C.; He, J.; Zhou, Q.; Shi, X.; Fang, J.; Jiang, B.-H. Reactive Oxygen Species Regulate Epidermal Growth Factor-Induced Vascular Endothelial Growth Factor and Hypoxia-Inducible Factor-1alpha Expression through Activation of AKT and P70S6K1 in Human Ovarian Cancer Cells. Free Radic. Biol. Med. 2006, 41, 1521-1533. [CrossRef]

227. Madge, L.A.; Pober, J.S. A Phosphatidylinositol 3-Kinase/Akt Pathway, Activated by Tumor Necrosis Factor or Interleukin-1, Inhibits Apoptosis but Does Not Activate NFkappaB in Human Endothelial Cells. J. Biol. Chem. 2000, 275, 15458-15465. [CrossRef] 
228. Liu, S.; Shen, H.; Xu, M.; Liu, O.; Zhao, L.; Liu, S.; Guo, Z.; Du, J. FRP Inhibits Ox-LDL-Induced Endothelial Cell Apoptosis through an Akt-NF-\{kappa\}B-Bcl-2 Pathway and Inhibits Endothelial Cell Apoptosis in an ApoE-Knockout Mouse Model. Am. J. Physiol. Endocrinol. Metab. 2010, 299, E351-E363. [CrossRef]

229. Massacesi, C.; Di Tomaso, E.; Urban, P.; Germa, C.; Quadt, C.; Trandafir, L.; Aimone, P.; Fretault, N.; Dharan, B.; Tavorath, R.; et al. PI3K Inhibitors as New Cancer Therapeutics: Implications for Clinical Trial Design. OncoTargets Ther. 2016, 9, $203-210$. [CrossRef] [PubMed]

230. Suvarna, V.; Murahari, M.; Khan, T.; Chaubey, P.; Sangave, P. Phytochemicals and PI3K Inhibitors in Cancer-An Insight. Front. Pharmacol. 2017, 8, 916. [CrossRef] [PubMed]

231. Mishra, R.; Patel, H.; Alanazi, S.; Kilroy, M.K.; Garrett, J.T. PI3K Inhibitors in Cancer: Clinical Implications and Adverse Effects. Int. J. Mol. Sci. 2021, 22, 3464. [CrossRef]

232. Niehrs, C. The Complex World of WNT Receptor Signalling. Nat. Rev. Mol. Cell Biol. 2012, 13, 767-779. [CrossRef]

233. Azbazdar, Y.; Karabicici, M.; Erdal, E.; Ozhan, G. Regulation of Wnt Signaling Pathways at the Plasma Membrane and Their Misregulation in Cancer. Front. Cell Dev. Biol. 2021, 9, 631623. [CrossRef] [PubMed]

234. Caspi, M.; Wittenstein, A.; Kazelnik, M.; Shor-Nareznoy, Y.; Rosin-Arbesfeld, R. Therapeutic Targeting of the Oncogenic Wnt Signaling Pathway for Treating Colorectal Cancer and Other Colonic Disorders. Adv. Drug Deliv. Rev. 2021, 169, 118-136. [CrossRef] [PubMed]

235. Li, X.; Ortiz, M.A.; Kotula, L. The Physiological Role of Wnt Pathway in Normal Development and Cancer. Exp. Biol. Med. Maywood NJ 2020, 245, 411-426. [CrossRef]

236. Bugter, J.M.; Fenderico, N.; Maurice, M.M. Mutations and Mechanisms of WNT Pathway Tumour Suppressors in Cancer. Nat. Rev. Cancer 2021, 21, 5-21. [CrossRef]

237. Rasola, A.; Fassetta, M.; De Bacco, F.; D’Alessandro, L.; Gramaglia, D.; Di Renzo, M.F.; Comoglio, P.M. A Positive Feedback Loop between Hepatocyte Growth Factor Receptor and Beta-Catenin Sustains Colorectal Cancer Cell Invasive Growth. Oncogene 2007, 26, 1078-1087. [CrossRef]

238. Smith, K.; Bui, T.D.; Poulsom, R.; Kaklamanis, L.; Williams, G.; Harris, A.L. Up-Regulation of Macrophage Wnt Gene Expression in Adenoma-Carcinoma Progression of Human Colorectal Cancer. Br. J. Cancer 1999, 81, 496-502. [CrossRef] [PubMed]

239. Ojalvo, L.S.; Whittaker, C.A.; Condeelis, J.S.; Pollard, J.W. Gene Expression Analysis of Macrophages That Facilitate Tumor Invasion Supports a Role for Wnt-Signaling in Mediating Their Activity in Primary Mammary Tumors. J. Immunol. 2010, 184, 702-712. [CrossRef]

240. Castellone, M.D.; Teramoto, H.; Williams, B.O.; Druey, K.M.; Gutkind, J.S. Prostaglandin E2 Promotes Colon Cancer Cell Growth through a Gs-Axin-Beta-Catenin Signaling Axis. Science 2005, 310, 1504-1510. [CrossRef]

241. Lopez-Bergami, P.; Barbero, G. The Emerging Role of Wnt5a in the Promotion of a Pro-Inflammatory and Immunosuppressive Tumor Microenvironment. Cancer Metastasis Rev. 2020, 39, 933-952. [CrossRef] [PubMed]

242. Asem, M.S.; Buechler, S.; Wates, R.B.; Miller, D.L.; Stack, M.S. Wnt5a Signaling in Cancer. Cancers 2016, 8, 79. [CrossRef] [PubMed]

243. Pereira, C.; Schaer, D.J.; Bachli, E.B.; Kurrer, M.O.; Schoedon, G. Wnt5A/CaMKII Signaling Contributes to the Inflammatory Response of Macrophages and Is a Target for the Antiinflammatory Action of Activated Protein C and Interleukin-10. Arterioscler. Thromb. Vasc. Biol. 2008, 28, 504-510. [CrossRef] [PubMed]

244. Ge, X.-P.; Gan, Y.-H.; Zhang, C.-G.; Zhou, C.-Y.; Ma, K.-T.; Meng, J.-H.; Ma, X.-C. Requirement of the NF-KB Pathway for Induction of Wnt-5A by Interleukin-1 $\beta$ in Condylar Chondrocytes of the Temporomandibular Joint: Functional Crosstalk between the Wnt-5A and NF-KB Signaling Pathways. Osteoarthr. Cartil. 2011, 19, 111-117. [CrossRef]

245. Catalán, V.; Gómez-Ambrosi, J.; Rodríguez, A.; Pérez-Hernández, A.I.; Gurbindo, J.; Ramírez, B.; Méndez-Giménez, L.; Rotellar F.; Valentí, V.; Moncada, R.; et al. Activation of Noncanonical Wnt Signaling through WNT5A in Visceral Adipose Tissue of Obese Subjects Is Related to Inflammation. J. Clin. Endocrinol. Metab. 2014, 99, E1407-E1417. [CrossRef]

246. Park, S.-Y.; Kang, M.-J.; Han, J.-S. Interleukin-1 Beta Promotes Neuronal Differentiation through the Wnt5a/RhoA/JNK Pathway in Cortical Neural Precursor Cells. Mol. Brain 2018, 11, 39. [CrossRef] [PubMed]

247. Linnskog, R.; Mohapatra, P.; Moradi, F.; Prasad, C.P.; Andersson, T. Demonstration of a WNT5A-IL-6 Positive Feedback Loop in Melanoma Cells: Dual Interference of This Loop More Effectively Impairs Melanoma Cell Invasion. Oncotarget 2016, 7, 37790-37802. [CrossRef]

248. Rozovski, U.; Harris, D.M.; Li, P.; Liu, Z.; Jain, P.; Ferrajoli, A.; Burger, J.A.; Bose, P.; Thompson, P.A.; Jain, N.; et al. STAT3-Induced Wnt5a Provides Chronic Lymphocytic Leukemia Cells with Survival Advantage. J. Immunol. 2019, 203, 3078-3085. [CrossRef]

249. Liu, Q.; Yang, C.; Wang, S.; Shi, D.; Wei, C.; Song, J.; Lin, X.; Dou, R.; Bai, J.; Xiang, Z.; et al. Wnt5a-Induced M2 Polarization of Tumor-Associated Macrophages via IL-10 Promotes Colorectal Cancer Progression. Cell Commun. Signal. CCS 2020, 18, 51. [CrossRef]

250. Chen, Y.; Chen, L.; Yu, J.; Ghia, E.M.; Choi, M.Y.; Zhang, L.; Zhang, S.; Sanchez-Lopez, E.; Widhopf, G.F.; Messer, K.; et al Cirmtuzumab Blocks Wnt5a/ROR1 Stimulation of NF-KB to Repress Autocrine STAT3 Activation in Chronic Lymphocytic Leukemia. Blood 2019, 134, 1084-1094. [CrossRef]

251. Barbero, G.; Castro, M.V.; Villanueva, M.B.; Quezada, M.J.; Fernández, N.B.; DeMorrow, S.; Lopez-Bergami, P. An Autocrine Wnt5a Loop Promotes NF-KB Pathway Activation and Cytokine/Chemokine Secretion in Melanoma. Cells 2019, 8, 1060. [CrossRef]

252. Ikeda, T.; Nishita, M.; Hoshi, K.; Honda, T.; Kakeji, Y.; Minami, Y. Mesenchymal Stem Cell-Derived CXCL16 Promotes Progression of Gastric Cancer Cells by STAT3-Mediated Expression of Ror1. Cancer Sci. 2020, 111, 1254-1265. [CrossRef] 
253. Bissell, M.J.; Hines, W.C. Why Don't We Get More Cancer? A Proposed Role of the Microenvironment in Restraining Cancer Progression. Nat. Med. 2011, 17, 320-329. [CrossRef]

254. Butti, R.; Nimma, R.; Kundu, G.; Bulbule, A.; Kumar, T.V.S.; Gunasekaran, V.P.; Tomar, D.; Kumar, D.; Mane, A.; Gill, S.S.; et al. Tumor-Derived Osteopontin Drives the Resident Fibroblast to Myofibroblast Differentiation through Twist1 to Promote Breast Cancer Progression. Oncogene 2021, 40, 2002-2017. [CrossRef]

255. Wei, Y.; Xiao, X.; Lao, X.-M.; Zheng, L.; Kuang, D.-M. Immune Landscape and Therapeutic Strategies: New Insights into PD-L1 in Tumors. Cell. Mol. Life Sci. CMLS 2021, 78, 867-887. [CrossRef] [PubMed]

256. Schmitt, M.; Greten, F.R. The Inflammatory Pathogenesis of Colorectal Cancer. Nat. Rev. Immunol. 2021. [CrossRef]

257. Rhodes, J.M.; Campbell, B.J. Inflammation and Colorectal Cancer: IBD-Associated and Sporadic Cancer Compared. Trends Mol. Med. 2002, 8, 10-16. [CrossRef]

258. De Pergola, G.; Silvestris, F. Obesity as a Major Risk Factor for Cancer. J. Obes. 2013, 2013, 291546. [CrossRef]

259. Weaver, V.M.; Petersen, O.W.; Wang, F.; Larabell, C.A.; Briand, P.; Damsky, C.; Bissell, M.J. Reversion of the Malignant Phenotype of Human Breast Cells in Three-Dimensional Culture and in Vivo by Integrin Blocking Antibodies. J. Cell Biol. 1997, 137, 231-245. [CrossRef] [PubMed]

260. Kumar, A.; Swain, C.A.; Shevde, L.A. Informing the New Developments and Future of Cancer Immunotherapy: Future of Cancer Immunotherapy. Cancer Metastasis Rev. 2021. [CrossRef]

261. Zhong, S.; Jeong, J.-H.; Chen, Z.; Chen, Z.; Luo, J.-L. Targeting Tumor Microenvironment by Small-Molecule Inhibitors. Transl. Oncol. 2020, 13, 57-69. [CrossRef]

262. Zak, K.M.; Grudnik, P.; Guzik, K.; Zieba, B.J.; Musielak, B.; Dömling, A.; Dubin, G.; Holak, T.A. Structural Basis for Small Molecule Targeting of the Programmed Death Ligand 1 (PD-L1). Oncotarget 2016, 7, 30323-30335. [CrossRef]

263. Zollo, M.; Di Dato, V.; Spano, D.; De Martino, D.; Liguori, L.; Marino, N.; Vastolo, V.; Navas, L.; Garrone, B.; Mangano, G.; et al. Targeting Monocyte Chemotactic Protein-1 Synthesis with Bindarit Induces Tumor Regression in Prostate and Breast Cancer Animal Models. Clin. Exp. Metastasis 2012, 29, 585-601. [CrossRef] [PubMed]

264. Grither, W.R.; Longmore, G.D. Inhibition of Tumor-Microenvironment Interaction and Tumor Invasion by Small-Molecule Allosteric Inhibitor of DDR2 Extracellular Domain. Proc. Natl. Acad. Sci. USA 2018, 115, E7786-E7794. [CrossRef] [PubMed]

265. Chames, P.; Van Regenmortel, M.; Weiss, E.; Baty, D. Therapeutic Antibodies: Successes, Limitations and Hopes for the Future. Br. J. Pharmacol. 2009, 157, 220-233. [CrossRef] [PubMed]

266. Furukawa, N.; Popel, A.S. Peptides That Immunoactivate the Tumor Microenvironment. Biochim. Biophys. Acta Rev. Cancer 2021, 1875, 188486. [CrossRef] [PubMed]

267. Lau, J.L.; Dunn, M.K. Therapeutic Peptides: Historical Perspectives, Current Development Trends, and Future Directions. Bioorg. Med. Chem. 2018, 26, 2700-2707. [CrossRef] [PubMed] 